\title{
Influence of large-scale atmospheric circulation patterns on nutrient dynamics in the Mediterranean Sea in the extended winter season (October-March) 1961-1999
}

\author{
M. Reale ${ }^{1,2, *}$, S. Salon ${ }^{2}$, S. Somot ${ }^{3}$, C. Solidoro ${ }^{2}$, F. Giorgi ${ }^{1}$, A. Crise ${ }^{2}$, G. Cossarini ${ }^{2}$, \\ P. Lazzari ${ }^{2}$, F. Sevault ${ }^{3}$ \\ ${ }^{1}$ ESP, Abdus Salam ICTP, Strada costiera 11, 34151 Trieste , Italy \\ ${ }^{2}$ OGS-National Institute of Oceanography and Experimental Geophysics, Via Beirut, 2-4, 34151 Trieste, Italy \\ ${ }^{3}$ CNRM, Université de Toulouse, Météo-France, CNRS, 31057 Toulouse, France
}

\begin{abstract}
We investigated the effects of variations in the 4 primary mid-latitude large-scale atmospheric circulation patterns on nutrients potentially limiting phytoplankton growth in the Mediterranean Sea (nitrate and phosphate), with a focus on the key deep convective areas of the basin (Gulf of Lions, Southern Adriatic Sea, Southern Aegean Sea and Rhodes Gyre). Monthly indices of these 4 modes of variability, together with a high-resolution hindcast of the Mediterranean Sea physics and biogeochemistry covering the period 1961-1999, were used to determine the physical mechanisms explaining the influence of these patterns on nutrient distribution and variability. We found a decrease in the concentration of phosphate and nitrate for each unit of increase in the index values of the East Atlantic and East Atlantic/West Russian variability modes in the area of the Gulf of Lions, while a signal of the opposite sign was associated with the North Atlantic Oscillation in the Aegean Sea and Rhodes Gyre. In both cases, the variability observed was related to a significant variation in the mixed layer depth driven by heat losses and wind stress over the areas. The East Atlantic pattern played a major role in driving the long-term dynamics of both phosphate and nitrate availability in the Gulf of Lions, with a particularly pronounced effect in December and January. For both the Aegean Sea and Rhodes Gyre, the most prominent correlations were found between the North Atlantic Oscillation and phosphate, with a highly consistent behavior in the 2 areas associated with common physical forcing and exchange of properties among them.
\end{abstract}

KEY WORDS: Mediterranean Sea $\cdot$ Large-scale atmospheric circulation patterns $\cdot$ Phosphate Nitrate $\cdot$ Mixed layer depth

\section{INTRODUCTION}

The Mediterranean region (Fig. 1) is a mid-latitude area consisting of several continental regions (southern Europe, northern Africa and the Middle East) surrounding a semi-enclosed basin, the Mediterranean Sea. The region is located in a transitional zone between 2 different climate regimes,

\footnotetext{
${ }^{*}$ Corresponding author: mreale@inogs.it
}

i.e. the sub-tropical climate of northern Africa and the temperate climate of central Europe, and is characterized by a complex land-sea physiography which locally affects atmospheric and ocean circulations. Moreover, the Mediterranean Sea acts as a source of moisture and heat, strengthening local cyclogenesis processes (Lionello et al. 2012 and references therein). The presence of densely popu-

(C) The authors 2020. Open Access under Creative Commons by Attribution Licence. Use, distribution and reproduction are unrestricted. Authors and original publication must be credited. 


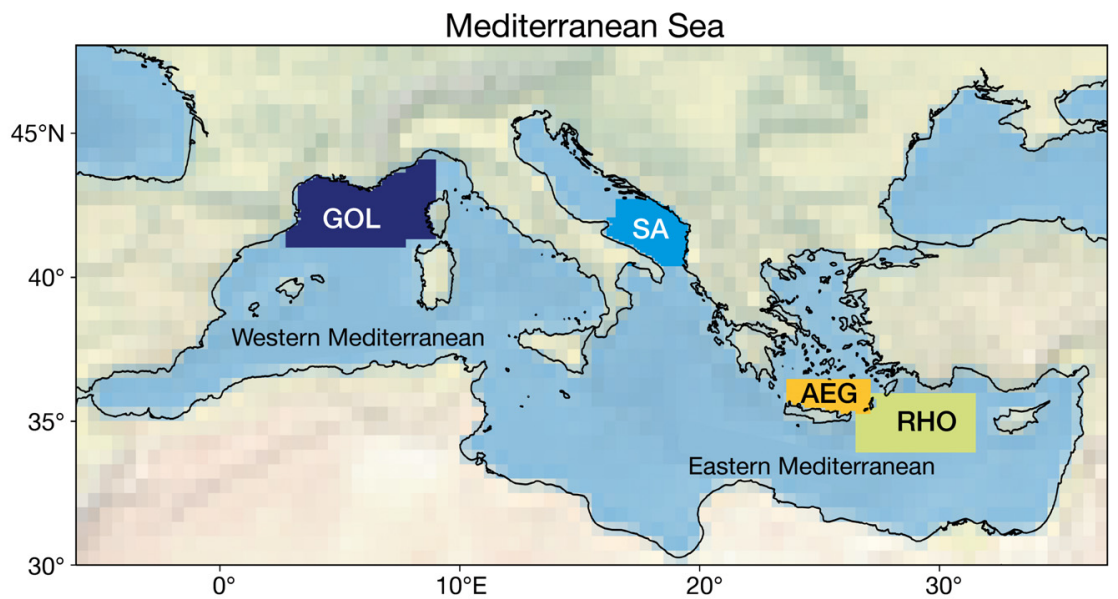

Fig. 1. Mediterranean Region: Western and Eastern Mediterranean Sea and areas selected for analysis: Gulf of Lions (GOL, blue), Southern Adriatic (SA, light blue), Southern Aegean Sea (AEG, orange) and Rhodes Gyre (RHO, green)
Papadopoulos et al. 2012). The positive state of the EAWR pattern exhibits a positive SLP anomaly over the North Sea and a negative SLP anomaly over Western Russia. It is associated with positive (negative) heat loss anomalies over the Western (Eastern) Mediterranean with a strong impact on the Aegean Sea heat balance (Xoplaki 2002, Josey et al. 2011, Papadopoulos et al. 2012). Finally, the SCAN is characterized by a positive SLP anomaly located over Scandinavia and a negative SLP anomaly over the Iberian Peninsula, and has been recognized as driving precipitation anomalies over the region (Xoplaki 2002, Josey et al. 2011).

The Mediterranean thermohaline circulation is characterized by the presence of deep-water formation processes in both its Western and Eastern basins (Schroeder et al. 2012 and references therein, Pinardi et al. 2019), and in particular by the presence of 3 thermohaline cells. The first is an open cell associated with the inflow of Atlantic Water at the Strait of Gibraltar forming the Algerian Current that eventually reaches the Eastern Mediterranean (Millot 1999, Pinot et al. 2002, Schroeder et al. 2012). Since the basin is widely recognized as a concentration basin (evaporation is higher than precipitation and river runoff), its upper layer experiences a progressive increase in salinity. In winter, a dense water formation process takes place in the Levantine Basin, in the Rhodes Gyre area (e.g. Marullo et al. 2003, Fig. 1), which produces the Levantine Intermediate Water, i.e. an intermediate-depth water mass located between 200 and $500 \mathrm{~m}$, which eventually outflows through the Strait of Gibraltar into the Atlantic Ocean (Lascaratos 1993, Nittis \& Lascaratos 1998). In addition to this intermediate open cell, the Mediterranean thermohaline circulation is characterized by 2 deep and closed cells driven by strong air-sea interactions in the area of the Gulf of Lions (Herrmann et al. 2010, Schroeder et al. 2012, 2016, Somot et al. 2018; Fig. 1) and in the Southern Adriatic Sea (Manca et al. 2004, Mantziafou \& Lascaratos 2004, 2008, Gačić et al. 2010, Reale et al. 2016, 2017, Teruzzi et al. 2016; Fig. 1). In particular, during the 1990s, the latter underwent a dramatic change consisting of a shift of deep-water formation processes from the Adriatic Sea to the Southern Aegean Sea (Fig. 1, Lascaratos et al. 1999, Theocharis et al. 2002, Roether et al. 2007). This event, known as Eastern Mediterranean Tranean region (e.g. Sáenz et al. 2001, Josey et al. 2011, 
sient, has been associated with anomalous winter conditions over the area (Beuvier et al. 2010, Josey et al. 2011), and more recently has been considered as a possible clue of the existence of multi-equilibrium states in the thermohaline cell of the Eastern Mediterranean (Ashkenazy et al. 2012, Amitai et al. 2017, Reale et al. 2017).

From a biogeochemical point of view, the Mediterranean Sea is considered an oligotrophic basin with low annual primary production (Sournia 1973, Azov 1991, Robarts et al. 1996, Moutin \& Raimbault 2002, Siokou-Frangou et al. 2010, Lazzari et al. 2012, Di Biagio et al. 2019, Reale et al. 2020) and a negative west-east trophic gradient in productivity and nutrient availability, namely nitrate $\left(\mathrm{NO}_{3}\right)$ and phosphate $\left(\mathrm{PO}_{4}\right)($ Crise et al. 1999, D'Ortenzio \& Ribera d'Alcalà 2009, Lazzari et al. 2012, 2016, Richon et al. 2018a,b, 2019, Di Biagio et al. 2019, Reale et al. 2020). The cause of this oligotrophy is ascribed to the relative nutrient-depleted Atlantic water entering the Strait of Gibraltar and undergoing a further depletion of nutrients while moving eastwards across the basin. This results in a net carbon and nutrient export to intermediate and deep waters (Crise et al. 1999, Crispi et al. 2001, Lazzari et al. 2016, Di Biagio et al. 2019). The atmospheric terrestrial input of nutrients through atmospheric deposition and riverine input is not sufficient to mitigate the oligotrophy of the euphotic zone of the basin (Crispi et al. 2001), which determines a sub-tropical-like regime for the marine ecosystem of the Mediterranean Sea (Pasqueron de Fommervault et al. 2015).

Exceptions to this general picture are some coastal shelves influenced by rivers and coastal processes (including the Rhone shelf, Northern Adriatic Sea, Northern Aegean Sea and Nile delta, among others) and some major open-ocean convective areas (Gulf of Lions, Southern Adriatic Sea, Aegean Sea, Rhodes Gyre) where the concentrations of $\mathrm{PO}_{4}$ and $\mathrm{NO}_{3}$ in the euphotic zone are higher as a consequence of the prevailing cyclonic circulation and energetic vertical mixing associated with intense air-sea interactions during winter (Crise et al. 1999, D'Ortenzio \& Ribera d'Alcalà 2009, Lazzari et al. 2016, Richon et al. 2018a, b). This condition favors the phytoplankton growth in the late winter-early spring when stratification is reestablished (D'Ortenzio \& Ribera d'Alcalà 2009, Herrmann et al. 2013, Auger et al. 2014) and phytoplankton is concentrated again in the euphotic zone ('GranSverdrup effect,' Mann \& Lazier 1991; 'dilutionrecoupling hypothesis,' Behrenfeld 2010). This establishes temperate-like regime conditions (Pasqueron de Fommervault et al. 2015) with relatively large chloro- phyll a (chl a) concentrations (D'Ortenzio \& Ribera d'Alcalà 2009, Lazzari et al. 2012).

In light of the prominent role played by the atmospheric forcing in the mechanical fertilization of the upper ocean, it is important to investigate the role played by large-scale atmospheric circulation patterns (LACPs) in the nutrient dynamics of the Mediterranean Sea euphotic zone, and to evaluate the long-term variability in the underlying mechanism. To our knowledge, while many studies have investigated the effect of deep convection on nutrients and low trophic levels (e.g. Auger et al. 2014, Macias et al. 2018 and references therein), only limited work has thus far focused on the influence of LACPs on the winter vertical mixing and nutrient supply in the euphotic layer (e.g. Polovina et al. 1995 for the Pacific Ocean). Moreover, while some studies have pointed out the influence of the NAO on zooplankton communities in the Northern Adriatic Sea (Piontkovski et al. 2011) and Western Mediterranean (García-Comas et al. 2011), on net primary production in the Western Mediterranean (Macias et al. 2015) and on chl $a$ in the Mediterranean Sea (Katara et al. 2008, Basterretxea et al. 2018), no studies to date have quantified the impacts of LACPs on nutrient dynamics and the main atmospheric drivers that affect the vertical water column stability and, in turn, the nutrient concentrations.

Thus, using for the first time a high-resolution hindcast of the Mediterranean Sea physics and biogeochemistry covering the period 1961-1999 and an approach already adopted for the analysis of heat flux variability (Josey et al. 2011) and deep-water formation processes (Papadopoulos et al. 2012), the effects of variations of the main 4 LACPs (NAO, EA, EAWR and SCAN) on the dynamics of both $\mathrm{PO}_{4}$ and $\mathrm{NO}_{3}$ in the euphotic layer (which, in this study, is assumed to span the upper $100 \mathrm{~m}$ of the water column) of the Mediterranean Sea are investigated. In particular, we focus on the main convection areas of the basin (Fig. 1), namely the Gulf of Lions, Southern Adriatic Sea, Southern Aegean Sea and Rhodes Gyre, and on the physical mechanisms explaining the influence of these patterns on nutrient distribution and variability.

In addition, we selected the extended cold season (October-March, hereafter ONDJFM, Josey et al. 2011, Papadopoulos et al. 2012) for our analysis because it is the period in which many studies have identified the influence of LACPs on the Mediterranean atmosphere/ocean dynamics, and when heat fluxes and density anomalies are more pronounced (Josey et al. 2011, Papadopoulos et al. 2012). 


\section{DATA AND METHODS}

The dataset used in this work consists of 2D fields of total heat fluxes, wind stress and mixed layer depth, along with 3D fields of $\mathrm{PO}_{4}$ and $\mathrm{NO}_{3}$ extracted from a simulation covering the period January 1961-December 1999 and built using the transportbiogeochemical model OGSTM-BFM forced in an off-line mode by daily physical variables from the NEMOMED8 ocean model. The period chosen for the analysis reflects the period covered by the original NEMOMED8 physical hindcast; only recently has the latter been extended to 2008. However, this part of the simulation was not available at the time of preparation of the biogeochemical hindcast, and thus the analysis is limited to the period January 1961December 1999

The NEMOMED8 model is described by Beuvier et al. (2010), and the specific hindcast simulation used here is detailed and evaluated by Herrmann et al. (2010), Meyssignac et al. (2011), Pascual et al. (2014), Soto-Navarro et al. (2015), Reale et al. $(2016,2017)$ and Dunić et al. (2018). It provides daily values of the physical forcing (3D current, potential temperature, salinity, net shortwave radiation, wind stress and vertical eddy diffusivity) which drives the dynamics of OGSTM-BFM. The NEMOMED8 hindcast has a 9$12 \mathrm{~km}$ horizontal resolution from north to south and 43 unequally spaced vertical z-levels. NEMOMED8 is driven by the atmospheric forcing from the socalled ARPERA dynamical downscaling of the ERA40 reanalysis (Herrmann \& Somot 2008, Herrmann et al. 2010). The use of the spectral nudging technique within ARPERA ensures that the high-resolution regional climate model follows the large-scale chronology of the driving reanalysis. If we assume that ERA40 reproduces well the observed chronology of the large-scale atmospheric circulation, then the largescale atmospheric patterns imposed to the ocean model by ARPERA are also close to reality. OGSTMBFM is a coupled physical-biogeochemical model composed by the transport model OGSTM (Foujols et al. 2000) and the biogeochemical reactor BFM (Vichi et al. 2013).

The main parameters and setup for the numerical experiment used in this work are summarized in Table 1. Biogeochemical initial conditions for $\mathrm{PO}_{4}$ nitrate, silicate and dissolved oxygen are obtained by spatial interpolation of the vertical climatological profiles available for the Mediterranean sub-basins in the MEDAR/MEDATLAS dataset (MEDAR Group 2003, Manca et al. 2004). As boundary conditions at Gibraltar, the model uses seasonal profiles of $\mathrm{PO}_{4}, \mathrm{NO}_{3}$, silicate and dissolved oxygen derived from the MEDAR-MEDATLAS dataset outside Gibraltar. Lateral boundary conditions for alkalinity and dissolved inorganic carbon are derived from Cossarini et al. (2015) which, in turn, are based on Dafner et al. (2001) and Huertas et al. (2009). For the atmospheric deposition rates of inorganic nitrogen and phosphorus, the numerical experiment uses the climatological values of Ribera d'Alcalà et al. (2003). Finally, monthly nutrient loads from rivers and other coastal nutrient sources are set according to Ludwig et al. (2009).

Table 1. Main parameters and settings for the modeling system (NEMOMED8-OGSTM-BFM)

\begin{tabular}{|c|c|}
\hline & Settings \\
\hline \multicolumn{2}{|l|}{ NEMOMED8 } \\
\hline Configuration & Hydrostatic \\
\hline Horizontal resolution & $9-12 \mathrm{~km}$ \\
\hline Vertical resolution & 43 unevenly spaced vertical levels \\
\hline Variables provided to daily offline coupling & $\begin{array}{l}\text { 3D current speed, temperature, salinity, short wave radiation, } 2 \mathrm{D} \text { wind } \\
\text { stress, vertical eddy diffusivity }\end{array}$ \\
\hline \multicolumn{2}{|r|}{ 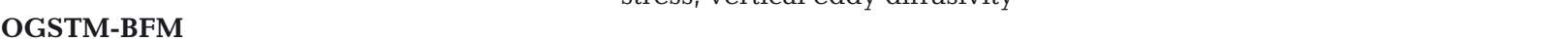 } \\
\hline Timestep & $1800 \mathrm{~s}$ \\
\hline Advective scheme for tracers & $\begin{array}{l}\text { Positive definite advection scheme with small implicit diffusion (Smolar- } \\
\text { kiewicz 1983) }\end{array}$ \\
\hline Initial conditions & $\begin{array}{l}\text { MEDAR-MEDATLAS dataset for dissolved oxygen, } \mathrm{NO}_{3}, \mathrm{PO}_{4} \text { and silicate; } \\
\text { BFM standard values for all the others biogeochemical variables }\end{array}$ \\
\hline Lateral boundary conditions & $\begin{array}{l}\text { MEDAR-MEDATLAS dataset for dissolved oxygen, } \mathrm{NO}_{3}, \mathrm{PO}_{4} \text { and silicate; } \\
\text { alkalinity and dissolved organic carbon based on Cossarini et al. (2015); } \\
\text { BFM standard values for all other biogeochemical variables; atmospheric } \\
\text { deposition from Ribera d'Alcalà et al. (2003); river biogeochemical input } \\
\text { from Ludwig et al. (2009) }\end{array}$ \\
\hline
\end{tabular}



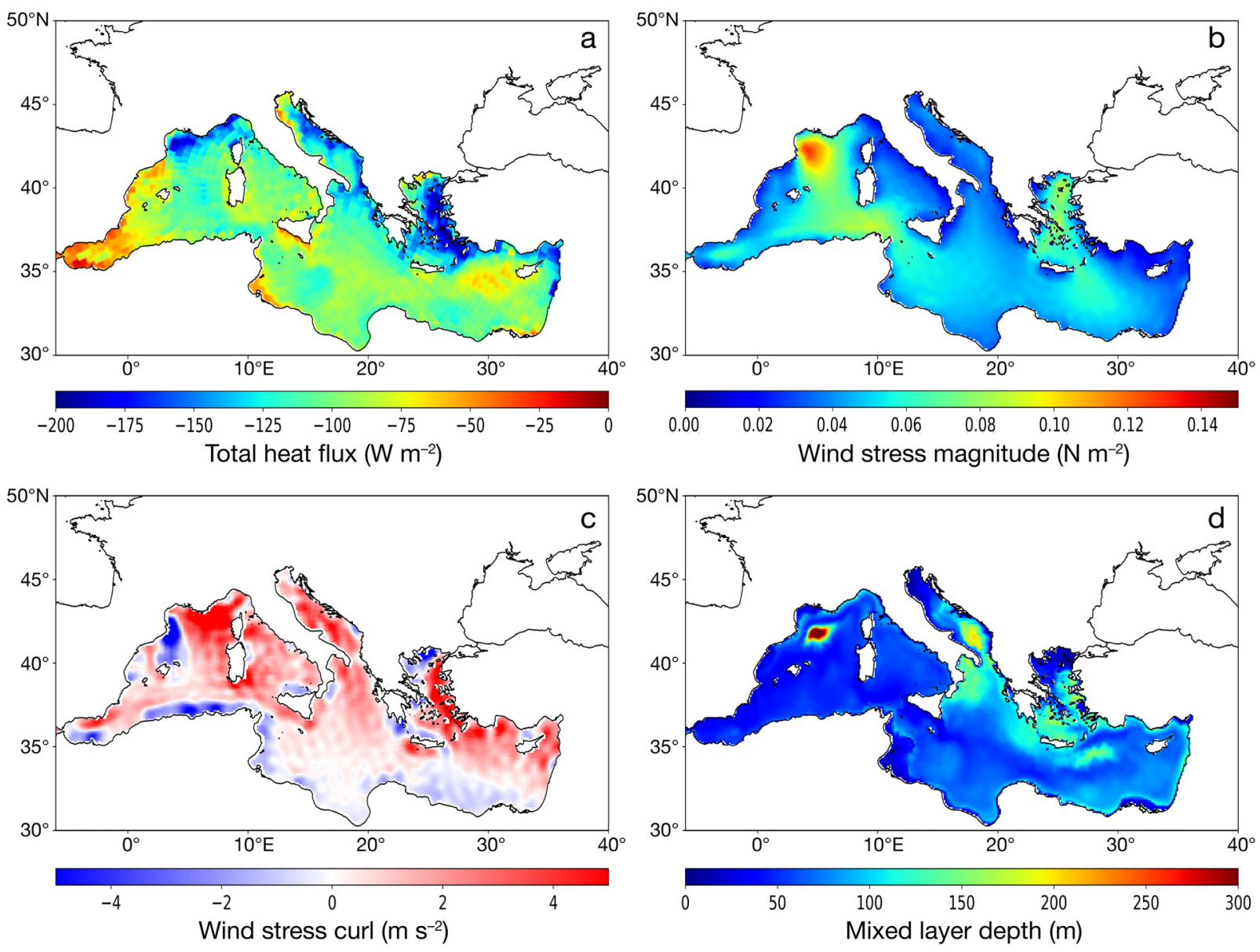

Fig. 2. Climatological winter (ONDJFM) means (1961-1999) of NEMOMED8-simulated: (a) total heat fluxes (W $\mathrm{m}^{-2}$ ), (b) wind stress magnitude $\left(\mathrm{N} \mathrm{m}^{-2}\right)$, (c) wind stress curl $\left(\mathrm{m} \mathrm{s}^{-2}\right)$, (d) mixed layer depth (m)

Climatological ONDJFM means of total heat fluxes, wind stress magnitude, wind stress curl and mixed layer depth are shown in Fig. 2. The distribution of relative mixed layer maxima in the basin corresponds to that identified in previous studies (e.g. D'Ortenzio et al. 2005, Houpert et al. 2015) and covers the main convective areas of the basin, i.e. the Gulf of Lions, Southern Adriatic Sea, Northern Ionian Sea, Aegean Sea and the area of the Rhodes Gyre. The Gulf of Lions and the Aegean Sea are areas in the basin characterized by intense heat losses (e.g. Josey et al. 2011, Papadopoulos et al. 2012). For the wind stress magnitude, relative maxima are located in correspondence of the Mistral (Gulf of Lions area) and Etesian wind patterns (Aegean and Rhodes Gyre area). Finally, concerning the wind stress curl, we observe the well-known decreasing north-south gradient, along with the bipolar structure of the wind stress curl over the Aegean due to the Etesian winds and over the Gulf of Lions due to the Mistral (e.g. Pinardi et al. 2006, Amitai et al. 2019).
Climatological ONDJFM means of $\mathrm{PO}_{4}$ and $\mathrm{NO}_{3}$ computed in the euphotic layer, simulated by NEMOMED8-OGSTM-BFM, are shown in Fig. 3 together with the seasonal cycles of both nutrients, as observed at the basin scale and in the areas shown in Fig. 1 for the NEMOMED8-OGSTM-BFM and CMEMS-MED-BIO datasets (Teruzzi et al. 2016). The latter is a biogeochemical dataset covering the period 1999-2015, built using the offline coupling between OGSTM-BFM and the physical reanalysis MyOcean, both produced and routinely updated within the Copernicus Marine Environmental Marine Service (Simoncelli et al. 2019, Teruzzi et al. 2019a). It has a horizontal resolution of $1 / 16^{\circ}$ and 72 vertical levels, and has already been used for validating different biogeochemical simulations in the Mediterranean Sea, such as those based on the MEDMIT12-BFM system (Di Biagio et al. 2019) and the RegCM-ES system (Reale et al. 2020). The use of the CMEMS physical reanalysis and the assimilation of chl a satellite data through the 3DVarBio scheme 

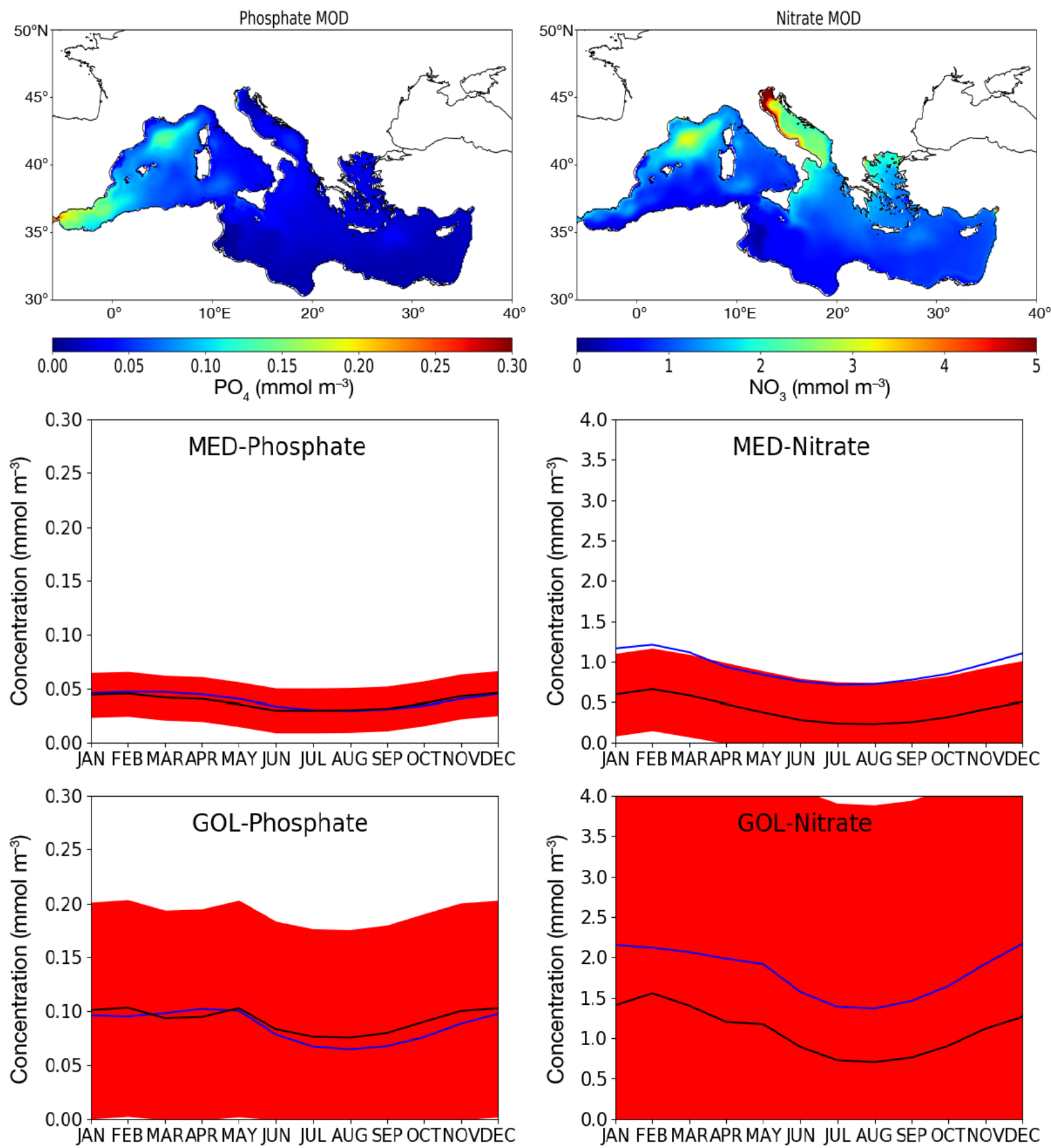

Fig. 3. Climatological winter (ONDJFM) means (1961-1999) in the euphotic layer of $\mathrm{PO}_{4}$ and $\mathrm{NO}_{3}$ simulated by NEMOMED8/ OGSTM-BFM and seasonal cycles of $\mathrm{PO}_{4}$ (left column) and $\mathrm{NO}_{3}$ (right column) based on NEMOMED8/OGSTM-BFM (blue line) and CMEMS-BIO (black line) datasets for the Gulf of Lions (GOL), Southern Adriatic (SA), Southern Aegean Sea (AEG) and Rhodes Gyre (RHO). The red area represents spread in the CMEMS-BIO data as measured by RMSD

Figure continued on next page

(see details in Teruzzi et al. 2014, 2018, 2019a,b) impose a constraint in the dataset on the seasonal dynamics of the nutrients, which are driven in the basin by both physical and biogeochemical processes. Thus here we compare the seasonal cycle of nutrients in both reanalysis and hindcast which is driven by the physical forcings acting on the area (modulated by LACPs) and the biogeochemical dynamics of the basin.

Our numerical experiment reproduces the westeast and north-south gradients of $\mathrm{PO}_{4}$ and $\mathrm{NO}_{3}$ in 

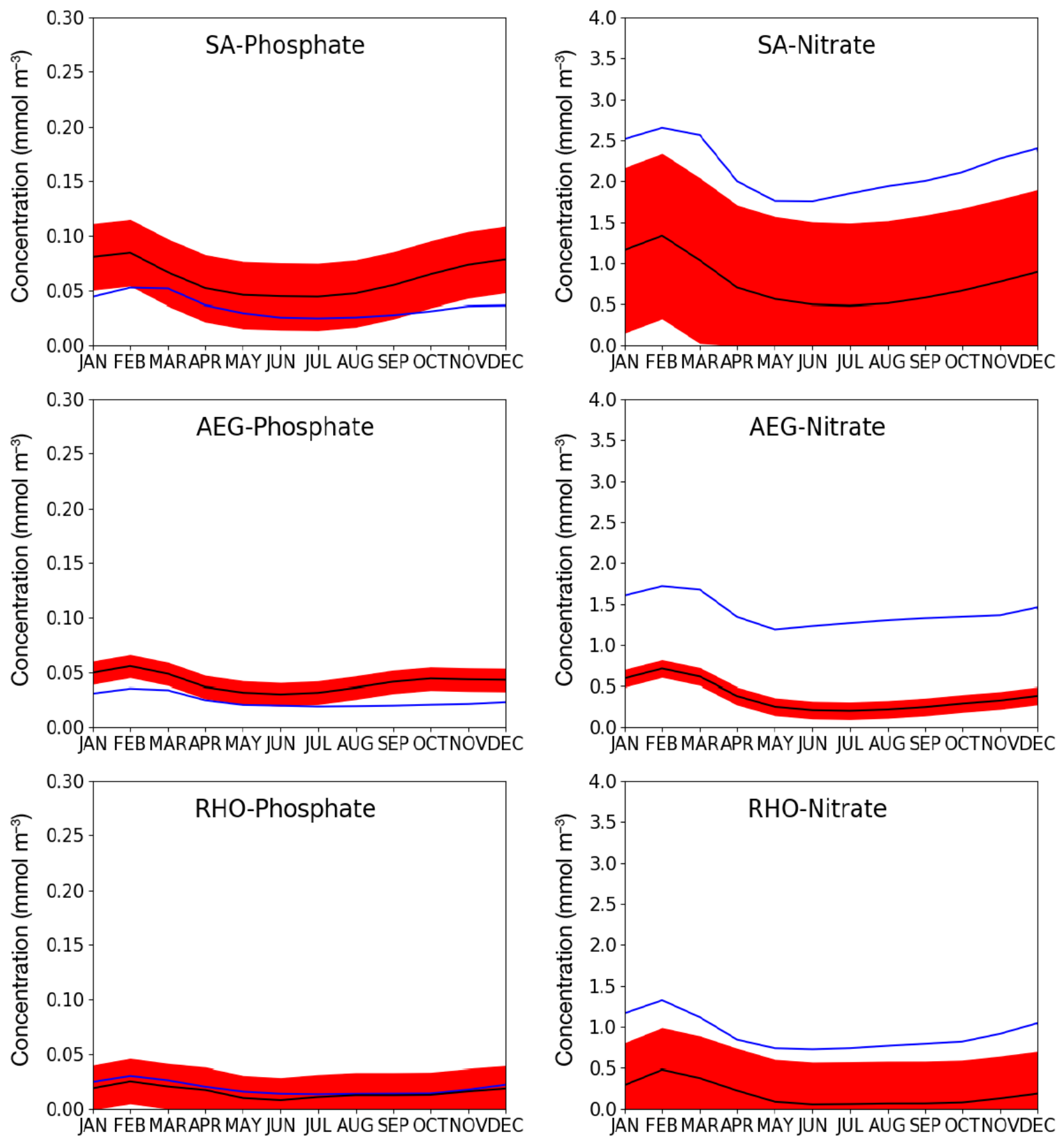

Fig. 3 (continued)

the basin, whose existence was pointed out in previous studies (e.g. Crise et al. 1999, Manca et al. 2004, Lazzari et al. 2016, Richon et al. 2018a,b, 2019, Di Biagio et al. 2019, Reale et al. 2020). Relative high values of $\mathrm{PO}_{4}$ are found in the Alboran Sea and Gulf of Lions (Crise et al. 1999, Manca et al. 2004, Lazzari et al. 2016, Richon et al. 2018a,b, Di Biagio et al. 2019, Reale et al. 2020), while relatively low $\mathrm{PO}_{4}$ val- ues are found in the Southern Adriatic, Northern Ionian, Aegean Sea and the Rhodes Gyre. In the case of $\mathrm{NO}_{3}$, intense signals are located in the Gulf of Lions, Adriatic Sea, Aegean Sea and Rhodes Gyre. The $\mathrm{NO}_{3}$ input from rivers in the Northern Adriatic (associated with the Po River inflow) and Aegean Sea (associated with the inflow at the Dardanelles Strait) is particularly remarkable, and is in good agreement with ded- 
icated regional studies (Solidoro et al. 2009, Souvermezoglou et al. 2014, Cossarini et al. 2015, 2017, Richon et al. 2018b, Di Biagio et al. 2019, Reale et al. 2020).

The seasonal cycle of both nutrients simulated by NEMOMED8-OGSTM-BFM is in good agreement with that observed in CMEMS-MED-BIO. Thus NEMOMED8-OGSTM-BFM is able to capture the seasonal variability of the biogeochemical variables in the convective areas of the basin, which is driven by both physical and biogeochemical processes. On the basin scale and in the Gulf of Lions, Southern Adriatic Sea, Southern Aegean Sea and Rhodes Gyre, NEMOMED8-OGSTM-BFM simulates monthly values of $\mathrm{PO}_{4}$ which tend to be within the range of the CMEMS-MED-BIO values. The same is found for $\mathrm{NO}_{3}$ on the basin scale and in the Gulf of Lions, even if a slight overestimation is observed in the Southern Adriatic Sea, in the Southern Aegean Sea and the Rhodes Gyre. Dynamics of the non-limiting nutrient $\left(\mathrm{NO}_{3}\right)$ tend to be overestimated in the run without assimilation (Teruzzi et al. 2018).

LACPs are commonly identified following an approach based on either neighboring maxima of anticorrelation or through a principal component analysis applied on SLP or $500 \mathrm{hPa}$ geopotential height (Wallace \& Gutzler 1981, Barnston \& Livezey 1987, Ulbrich et al. 2012). Following previous studies, in order to characterize the variability of LACPs and its impact on biological and physical variables, we use indexes updated on a monthly scale (www. cpc.ncep.noaa.gov/data/teledoc/telecontents.shtml). Since LACPs are computed by means of empirical orthogonal functions, we assume they do not interact with each other regardless of their effects on physical/biogeochemical variables. However, with the availability of monthly biogeochemical and physical variables, it is not possible to follow different approaches (such as $k$-cluster methods). Moreover, the approach based on monthly indexes is the same as adopted in numerous other studies correlating physical or biogeochemical variables with LACPs (e.g. Irigoien et al. 2000, Josey 2003, Josey et al. 2011, Beaugrand et al. 2012, Papadopoulos et al. 2012, Henson et al. 2013, Reale \& Lionello 2013). More specifically, in order to assess the sensitivity of the physical/biogeochemical variables to the different LACPs, we follow the approach described by Josey et al. (2011) and Papadopoulos et al. (2012).

First, the values for mixed layer depth, total heat fluxes, wind stress magnitude and curl, $\mathrm{PO}_{4}$ and $\mathrm{NO}_{3}$ are determined with a specific focus on the main con- vective areas of the basin shown in Fig. 1. If $X_{k, j}$ is the value of one of the aforementioned variables in month $j$ (with $j=1, \ldots, 12$ ) of year $k$ (with $k=1961, \ldots$, 1999), we consider only the monthly anomalies $\left(X_{k, j}^{\text {anom }}\right)$ with respect to the annual cycle $X_{j}^{\text {cycle }}$ computed over the period 1961-1999:

$$
X_{k, j}^{\text {anom }}=X_{k, j}-X_{j}^{\text {cycle }}
$$

All individual $X_{k, j}^{\text {anom }}$ for the ONDJFM during 19611999 corresponding to a monthly LACP index (Fig. 4) value $>1.5$ (or $<-1.5)$ are then selected $\left(X_{k, j}^{|\mathrm{LACP}|>1.5}\right.$, Josey et al. 2011, Papadopoulos et al. 2012). We selected $43 X_{k, j}^{|\mathrm{LACP}|>1.5}$, for both NAO and EA, 44 for EAWR and 39 for SCAN (Fig. 4). Finally, we divide $X_{k, j}^{|\mathrm{LACP}|>1.5}$ by the LACP index value for that month and then average the resulting anomalies in order to obtain a weighted mean $X_{\text {average }}^{\mathrm{LACP} \mid>1.5}$, which represents the variation of that variable $X$ for a unit of positive index value, i.e.:

$$
X_{\text {average }}^{\mathrm{LACP} \mid 1.5}=\frac{\left(\sum_{k, j} \frac{X_{k, j}^{\mathrm{LACP} \mid>1.5}}{\mathrm{LACP}}\right)}{N}
$$

where $\mathrm{N}=$ the number of months when the monthly LACP index value is $>1.5$ (or $<-1.5$ ). This weighted mean $X_{\text {average }}^{\mathrm{LACP} \mid>1.5}$ is then divided by the extended winter climatological value of $X_{\text {ONDJFM }}$ and multiplied by 100 in order to express the variation as a percentage with respect to the winter mean:

$$
X_{\text {percentage }}^{|\mathrm{LACP}|>1.5}=100 \times \frac{X_{\text {average }}^{|\mathrm{LACP}|>1.5}}{X_{\text {ONDJFM }}}
$$

We remove from our spatial averages $X_{\text {percentage }}^{\mid \mathrm{LACP}>1.5}$ all the areas with a depth less than $200 \mathrm{~m}$. In this way, we mask the effects of river runoff that can be substantial in coastal areas (as already observed before) and focus on the pelagic dynamics, which are more influenced by the air-sea interactions.

Data are considered statistically significant at the $95 \%$ confidence level.

\section{RESULTS}

\subsection{Impact of LACPs on biogeochemical and physical variables in the Mediterranean Sea}

Fig. 5 shows the composite of anomalous winter $\mathrm{PO}_{4}$ and $\mathrm{NO}_{3}$ concentrations in the euphotic zone for a unit of positive index value of the different LACPs in the Mediterranean Sea. Overall, the sensitivities of the $\mathrm{PO}_{4}$ and $\mathrm{NO}_{3}$ concentrations vary by 

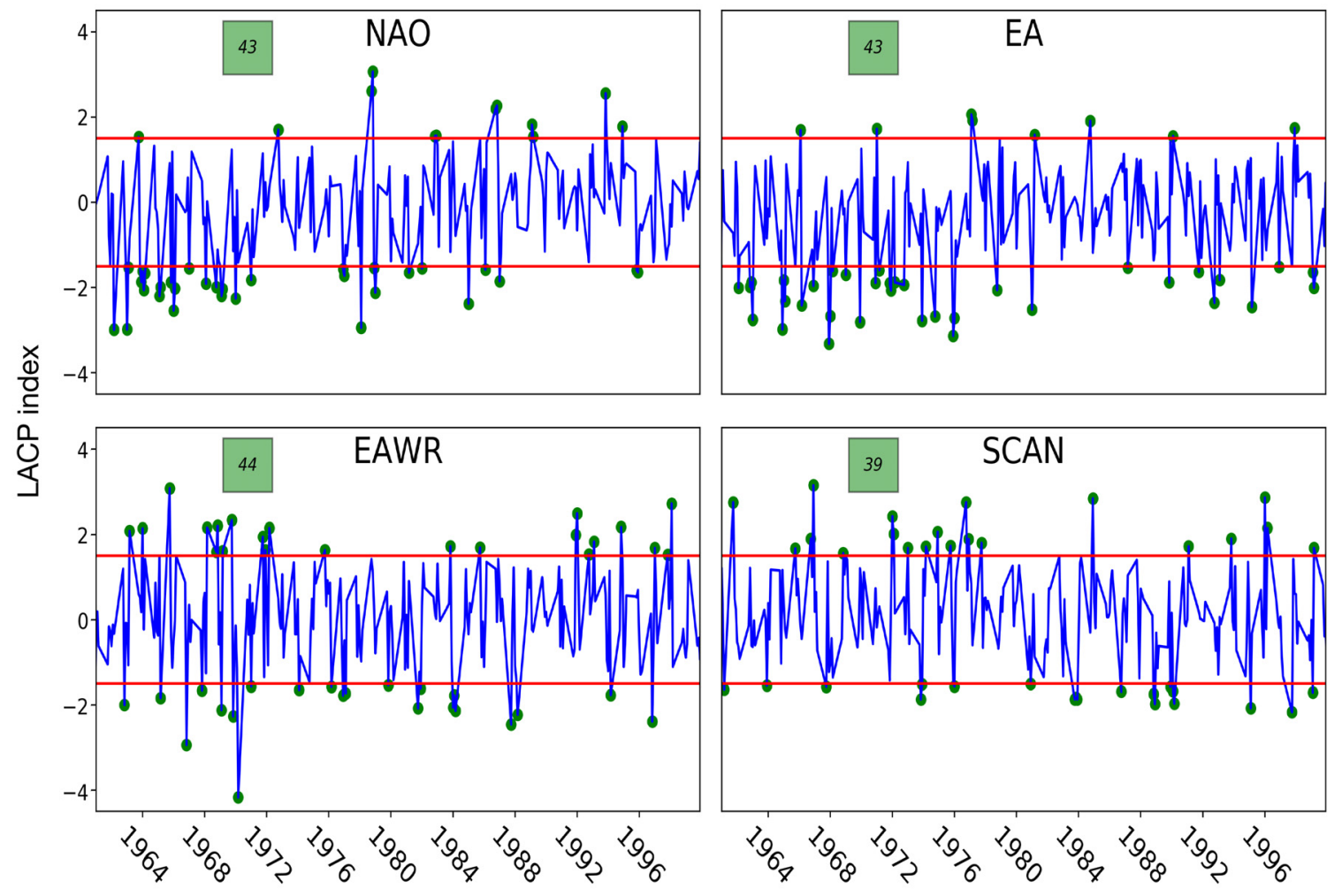

Fig. 4. Monthly timeseries of large-scale atmospheric circulation pattern (LACP) indices (considering only winter [ONDJFM] for each year) from 1961-1999. Green dots are the months when the LACP index is greater in absolute value than 1.5 (demarcated by red lines). Green squares show the total number of anomalous months found in each timeseries. NAO: North Atlantic

Oscillation, EA: East Atlantic pattern, EAWR: East Atlantic/West Russian pattern, SCAN: Scandinavian pattern

less than a few percent, but there are responses in specific areas worth discussing, since they constitute a part of the interannual variability. The effect of the variation in NAO (Fig. 5a), EA (Fig. 5c) and EAWR (Fig. 5e) is substantial in the area of the Gulf of Lions, which is characterized by a general decrease in $\mathrm{PO}_{4}$ concentration for a unit of positive index value. A similar response can be observed for $\mathrm{NO}_{3}$ (Fig. 5b,d,f). More specifically, the EA and EAWR have a strong primary influence on both $\mathrm{PO}_{4}$ and $\mathrm{NO}_{3}$ in the Gulf of Lions (Table 2), where, for each one-unit variation in the positive index, the mean anomaly of $\mathrm{PO}_{4}$ and $\mathrm{NO}_{3}$ lies in the interval $[-3,-2 \%]$. Similar values are found for the $\mathrm{NAO}$, although for $\mathrm{NO}_{3}$ the relationship with NAO is not statistically significant.

A decrease of $4 \%$ in the $\mathrm{PO}_{4}$ concentration is found in the case of the NAO in the Northern Ionian Sea (Fig. 5a), while an increase in $\mathrm{PO}_{4}$ concentration is observed in the Aegean and Rhodes areas. For $\mathrm{NO}_{3}$, only a slight increase in the concentration $(<1 \%)$ is observed in the Ionian (Fig. 5b), while positive signals (Fig. 5b) are associated with the NAO over the Aegean and Rhodes areas (as already observed for
$\mathrm{PO}_{4}$ ). Thus for both the Aegean Sea and Rhodes Gyre, the leading mode of variability is represented by the NAO, with anomalies for $\mathrm{PO}_{4}$ and $\mathrm{NO}_{3}$ of 9 and $7 \%$ for each index value unit in the Aegean Sea, respectively, and 5.8 and $5.6 \%$ in the Rhodes Gyre, respectively (Table 2 ). The positive signal of $\mathrm{NO}_{3}$ in the Southern Adriatic in response to the NAO and EA (Fig. 5b,d), i.e. 4.7 and $2.6 \%$, respectively (with the former statistically significant), has an opposite behavior with respect to that observed for $\mathrm{PO}_{4}$ (Fig. $5 \mathrm{a}, \mathrm{C}$ ), which in both cases is negative and not statistically significant (Table 2).

Other positive signals shared by both $\mathrm{PO}_{4}$ and $\mathrm{NO}_{3}$ are located in the Alboran Sea for the EA and EAWR (Fig. $5 \mathrm{c}, \mathrm{d}, \mathrm{e}, \mathrm{f}$ ) and in the Western Mediterranean in the case of the SCAN pattern (Fig. 5g,h), which are associated, albeit with anomalies in all the cases $<2 \%$ and not statistically significant. For the SCAN pattern, the signal is mostly weak $(<1 \%$ in absolute value) and negative in the Eastern Mediterranean for both $\mathrm{PO}_{4}$ and $\mathrm{NO}_{3}$. Since the SCAN pattern does not show any significant variation in nutrients for a positive index value unit, it will not be further considered in this work. 

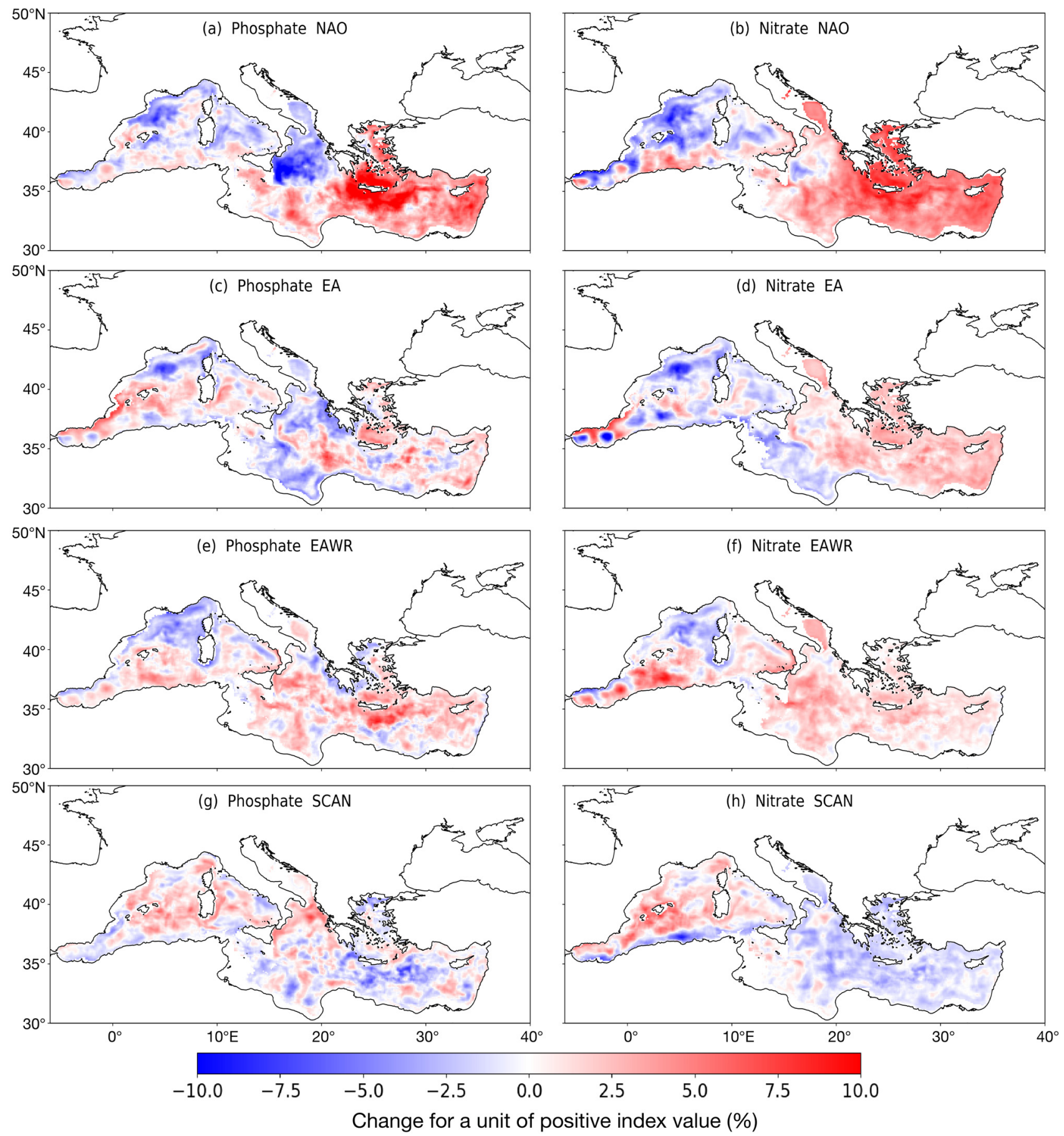

Fig. 5. Composite of anomalous winter (ONDJFM) concentrations of $(\mathrm{a}, \mathrm{c}, \mathrm{e}, \mathrm{g}) \mathrm{PO}_{4}$ and $(\mathrm{b}, \mathrm{d}, \mathrm{f}, \mathrm{h}) \mathrm{NO}_{3}$ for a unit of positive index value for each of the 4 main modes (abbreviations as in Fig. 4): (a,b) NAO, (c,d) EA, (e,f) EAWR and (g,h) SCAN. All values shown are percentages with respect to the climatological ONDJFM means

Composites of anomalous winter total heat fluxes, wind stress magnitude and curl, and mixed layer depth across the Mediterranean Sea are shown in Fig. 6 and Table 3. A variation of a unit of positive NAO index is associated with an increase of $2 \%$ (decrease of $9 \%$ ) in the total heat flux over the Gulf of
Lions (Eastern Mediterranean and Rhodes Gyre; Fig. 6a); an increase of 6 and $11 \%$ of wind stress magnitude over most of the Gulf of Lions and the Aegean Sea, respectively (Fig. 6b); a negative (positive) wind stress curl anomaly of approximately $10 \%$ over the Gulf of Lions (of 27 and $9 \%$ over the Aegean Sea and 
Table 2. Gulf of Lions (GOL), Southern Adriatic (SA), Aegean Sea (AEG) and Rhodes Gyre (RHO) climatological winter mean (clim; October-March) $\mathrm{PO}_{4}$ and $\mathrm{NO}_{3}$ concentrations for the period 1961-1999 in the first $100 \mathrm{~m}$ of the water column. Also shown are the averaged values (percentages with respect to the climatological winter mean) of the anomalous $\mathrm{PO}_{4}$ and $\mathrm{NO}_{3}$ for a positive index value unit of each of the 4 atmospheric modes (NAO: North Atlantic Oscillation; EA: East Atlantic pattern; EAWR: East Atlantic/West Russian pattern; SCAN: Scandinavian pattern). Bold: anomalies significantly different from zero according to Student's $t$-test (95\% confidence level)

\begin{tabular}{|lcccccccccc|}
\hline Area & $\begin{array}{c}\mathrm{PO}_{4} \mathrm{clim} \\
\left(\mathrm{mmol} \mathrm{m}^{-3}\right)\end{array}$ & $\begin{array}{c}\mathrm{NO}_{3} \mathrm{clim} \\
\left(\mathrm{mmol} \mathrm{m}^{-3}\right)\end{array}$ & $\begin{array}{c}\mathrm{PO}_{4 \mathrm{NAO}} \\
(\%)\end{array}$ & $\begin{array}{c}\mathrm{NO}_{3 \mathrm{NAO}} \\
(\%)\end{array}$ & $\begin{array}{c}\mathrm{PO}_{4 \mathrm{EA}} \\
(\%)\end{array}$ & $\begin{array}{c}\mathrm{NO}_{3 \mathrm{EA}} \\
(\%)\end{array}$ & $\begin{array}{c}\mathrm{PO}_{4 \mathrm{EAWR}} \\
(\%)\end{array}$ & $\begin{array}{c}\mathrm{NO}_{3 \mathrm{EAWR}} \\
(\%)\end{array}$ & $\begin{array}{c}\mathrm{PO}_{4 \mathrm{SCAN}} \\
(\%)\end{array}$ & $\begin{array}{c}\mathrm{NO}_{3 \mathrm{SCAN}} \\
(\%)\end{array}$ \\
\hline $\mathrm{GOL}$ & 0.1 & 2.03 & -2.1 & $\mathbf{- 3 . 1}$ & $\mathbf{- 2 . 4}$ & $\mathbf{- 3 . 1}$ & $\mathbf{- 2 . 9}$ & $\mathbf{- 2 . 2}$ & $<1$ & $<1$ \\
$\mathrm{SA}$ & 0.04 & 2.46 & -2.2 & $\mathbf{4 . 7}$ & -1.44 & 2.58 & 1 & 2.98 & $<1$ & -1.6 \\
$\mathrm{AEG}$ & 0.02 & 1.56 & $\mathbf{9}$ & $\mathbf{7}$ & 3 & 3 & 2.8 & 2 & $<1$ & -1.1 \\
$\mathrm{RHO}$ & 0.02 & 1.1 & $\mathbf{5 . 8}$ & $\mathbf{5 . 6}$ & 1.1 & 2.2 & 2.7 & 1.4 & -1.8 & -1.4 \\
\hline
\end{tabular}
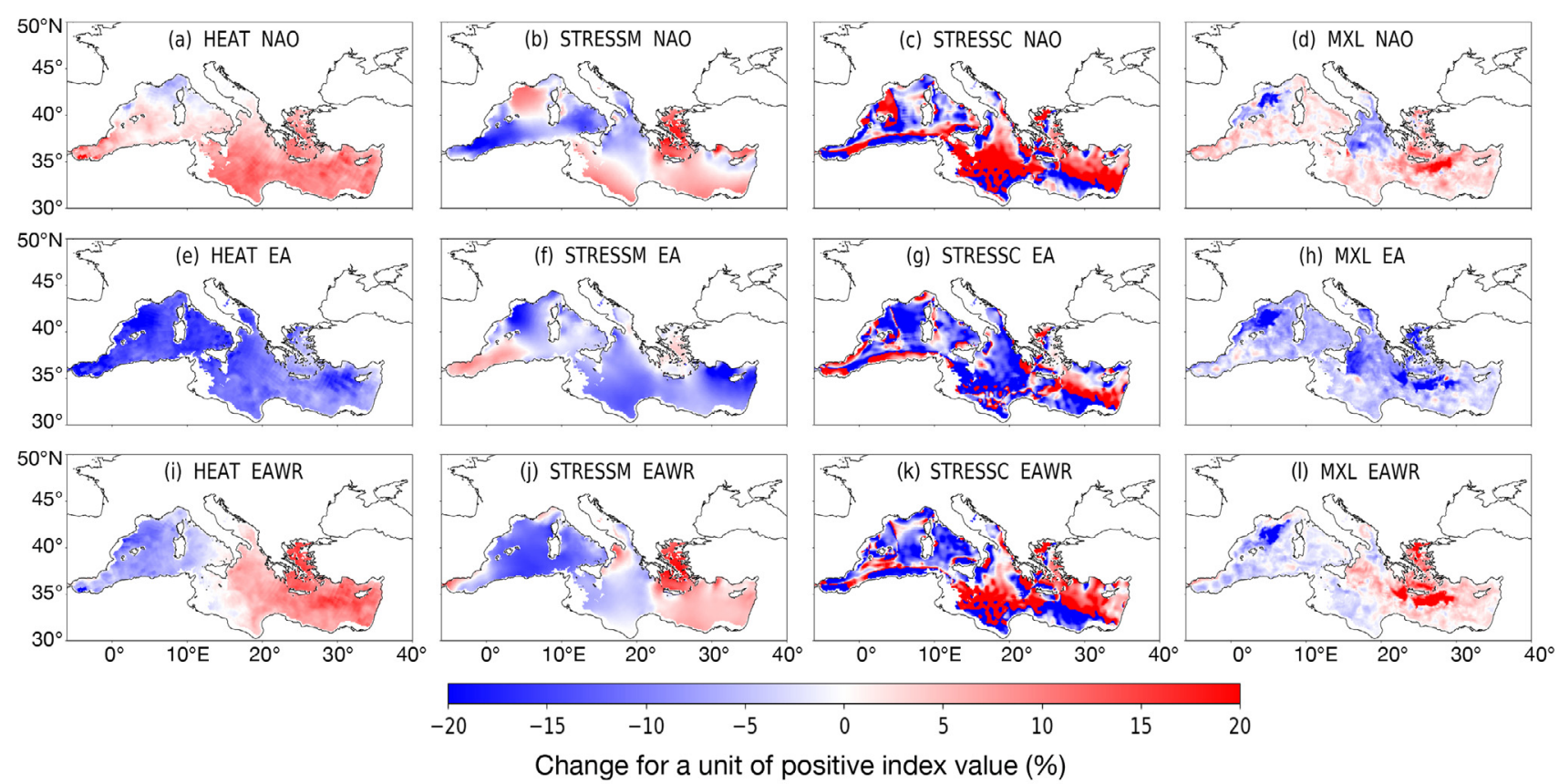

Fig. 6. As in Fig. 5, but for total heat fluxes (HEAT, first column), wind stress magnitude (STRESSM, second column), wind stress curl (STRESSC, third column) and mixed layer depth (MXL, forth column) for NAO (first row), EA (second row) and EAWR (third row) (mode abbreviations as in Fig. 4)

Rhodes areas, respectively; Fig. 6c); and a decrease in mixed layer depth of approximately $10 \%$ in part of the Gulf of Lions limited southward by the Balearic Front, of $5 \%$ in the entire Northern Ionian and of $2 \%$ in the Southern Adriatic (an increase of approximately 9 and $12 \%$ over the Aegean Sea and the Rhodes Gyre, respectively; Fig. 6d). In the case of EA, a variation of a unit of positive EA index is associated with a strong reduction of approximately $11 \%$ of total heat flux loss over the entire basin (Fig. 6e), in particular over the Gulf of Lions (where the reduction is approximately $15 \%$, Josey et al. 2011, Papadopoulos et al. 2012), with the influence of this pattern becoming weaker moving eastwards (Josey et al. 2011).
The wind stress magnitude (wind stress curl) decreases by approximately $6 \%$ (becomes more negative by approximately $11 \%$ across the basin, with the exception of the westernmost Mediterranean Sea, where it increases approximately by $5 \%$ ) (Fig. 6f,g). In the Aegean, the wind stress curl tends to be more cyclonic by approximately 9\%. Finally, a general decrease of mixed layer thickness, about $7 \%$, is observed across the basin in response to a positive EA anomaly, particularly marked in the Gulf of Lions where it is equal to $21 \%$ (Fig. $6 \mathrm{~h}$ ).

A positive EAWR induces a dipole structure in both total heat flux (Fig. 6i) and wind stress magnitude/ curl (Fig. 6j,k), more specifically a negative/positive 
Table 3. As for Table 2 but for total heat fluxes (HEAT), wind stress magnitude (STRESSM), wind stress curl (STRESSC) and mixed layer depth (MXL), where units apply only to the

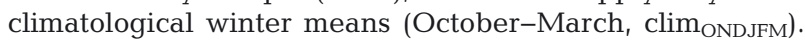
Other abbreviations as in Table 2

\begin{tabular}{|c|c|c|c|c|}
\hline & $\begin{array}{c}\text { HEAT } \\
\left(\mathrm{W} \mathrm{m}^{-2}\right)\end{array}$ & $\begin{array}{l}\text { STRESSM } \\
\left(\mathrm{N} \mathrm{m}^{-2}\right)\end{array}$ & $\begin{array}{l}\text { STRESSC } \\
\left(\mathrm{m} \mathrm{s}^{-2}\right)\end{array}$ & $\begin{array}{c}\text { MXL } \\
(\mathrm{m})\end{array}$ \\
\hline \multicolumn{5}{|c|}{$\operatorname{clim}_{\text {ONDJFM }}$} \\
\hline GOL & -128 & 0.07 & $2.70 \times 10^{-10}$ & 89 \\
\hline SA & -127 & 0.04 & $2.50 \times 10^{-10}$ & 149 \\
\hline AEG & -131 & 0.06 & $1.60 \times 10^{-10}$ & 116 \\
\hline $\mathrm{RHO}$ & -90 & 0.05 & $2.30 \times 10^{-10}$ & 81 \\
\hline \multicolumn{5}{|c|}{ NAO (\%) } \\
\hline GOL & -2 & 6 & -10 & -10 \\
\hline $\mathrm{SA}$ & $<1$ & -6 & -3 & -2 \\
\hline AEG & 9 & 11 & 27 & 8 \\
\hline RHO & 9 & 2 & 9 & 12 \\
\hline \multicolumn{5}{|c|}{ EA (\%) } \\
\hline GOL & -15 & -13 & -11 & -21 \\
\hline $\mathrm{SA}$ & -14 & -2 & -10 & -9 \\
\hline $\mathrm{AEG}$ & -8 & -0.40 & 9 & -6 \\
\hline RHO & -12 & -10 & 1 & -10 \\
\hline \multicolumn{5}{|c|}{ EAWR (\%) } \\
\hline GOL & -7 & -9 & -5 & -13 \\
\hline SA & 2 & -2 & -2 & $<1$ \\
\hline AEG & 11 & 12 & 26 & 11 \\
\hline RHO & 11 & 5 & 12 & 13 \\
\hline
\end{tabular}

change in the Western/Eastern Mediterranean (Josey et al. 2011, Papadopoulos et al. 2012). These anomalies are equal to -5 and $7 \%$ for the heat fluxes, -10 and $2 \%$ for the wind stress magnitude and -3 and $7 \%$ for the wind stress curl. In particular, a positive EAWR anomaly results in a more pronounced anticyclonic (cyclonic) anomaly over the Western (Eastern) Mediterranean Basin. The maximum variation of mixed layer depth (Fig. 6l) related to the EAWR is similar to that observed for the NAO, with a negative maximum variation in the Gulf of Lions and the area west of Sardinia and a positive maximum variation in the Aegean Sea and the Rhodes Gyre (13 and 11\% respectively). More specifically, in the Gulf of Lions, the EA and EAWR are the main drivers for the mixed layer variability (Table 3 ), with a reduction of about -21 and $-13 \%$ for a unit of positive index value, respectively. These negative variations are associated with a reduction in total heat flux over the area of -15 and $-7 \%$, a reduction in wind stress magnitude of -13 and $-9 \%$, and a reduction in wind stress curl of -11 and $-5 \%$ (not significant), respectively.

The NAO is the main driver of mixed layer variability in the Aegean Sea and the Rhodes Gyre, with an increase of about 8 and $12 \%$, respectively, for each index value unit, associated with a corresponding in- crease of total heat flux loss of about $9 \%$. Only in the Aegean Sea does the NAO appear to be associated with a significant variation in wind stress magnitude (about $11 \%$ ), while the curl increases by $27 \%$ for a unit of positive index value over the Aegean Sea and $9 \%$ over the Rhodes Gyre. Finally, in the Southern Adriatic, we did not find any statistically significant correlation for the variables considered, except for the relation of total heat flux and wind stress curl with the EA pattern $(-14$ and $-10 \%$, respectively). This implies that over the Southern Adriatic the local dynamics may be influenced by other factors such as advection related to the (locally relevant) Adriatic Ionian Bimodal Oscillating System (BiOS) dynamics (Gačić et al. 2010, Reale et al. 2016, 2017).

To summarize, a positive anomaly of the NAO, EA and EAWR indexes shows similar response patterns throughout the basin, roughly driving an east-west dipole structure in nutrient anomalies across the basin. The area of the Gulf of Lions experiences a decrease in nutrient concentrations in the euphotic zone, while the Alboran Sea and most of the Eastern basin are characterized by a slight increase in nutrient concentrations, with a peak signal in the Rhodes Gyre and the Aegean Sea (in the case of NAO). $\mathrm{PO}_{4}$ and $\mathrm{NO}_{3}$ in the Southern Adriatic are instead almost negatively correlated. Physical variables are also shown to be sensitive to the EA, EAWR and NAO variability due to the importance of these patterns in influencing the atmospheric flows over the Mediterranean region (Josey et al. 2011, Papadopoulos et al. 2012).

As shown by Josey et al. (2011), the negative phase of the EA pattern is associated with a high-pressure system in the Western Atlantic, with the Mediterranean region lying on its southeastern flank. This configuration induces a northerly flow which brings cold air over the Mediterranean Basin, inducing strong heat losses across the entire basin, and in particular over the Gulf of Lions. At the same time, the wind stress magnitude increases over most of the basin. When the EA is in its positive phase, these mechanisms reverse in sign, explaining the variations observed in Table 3 and Fig. 6e-h. Concerning the EAWR and NAO, the positive phase of both atmospheric patterns is associated with a cold northerly flow over the Eastern Mediterranean and warmer southeasterly airflow over the Western Mediterranean (Josey et al. 2011), which induce a dipole structure in the total heat fluxes and wind stress magnitude (Table 3, Fig. 6a, d,j,1).

$\mathrm{PO}_{4}, \mathrm{NO}_{3}$ and mixed layer depth anomalies (Figs. 5 \& 6) show similar spatial response patterns, deter- 

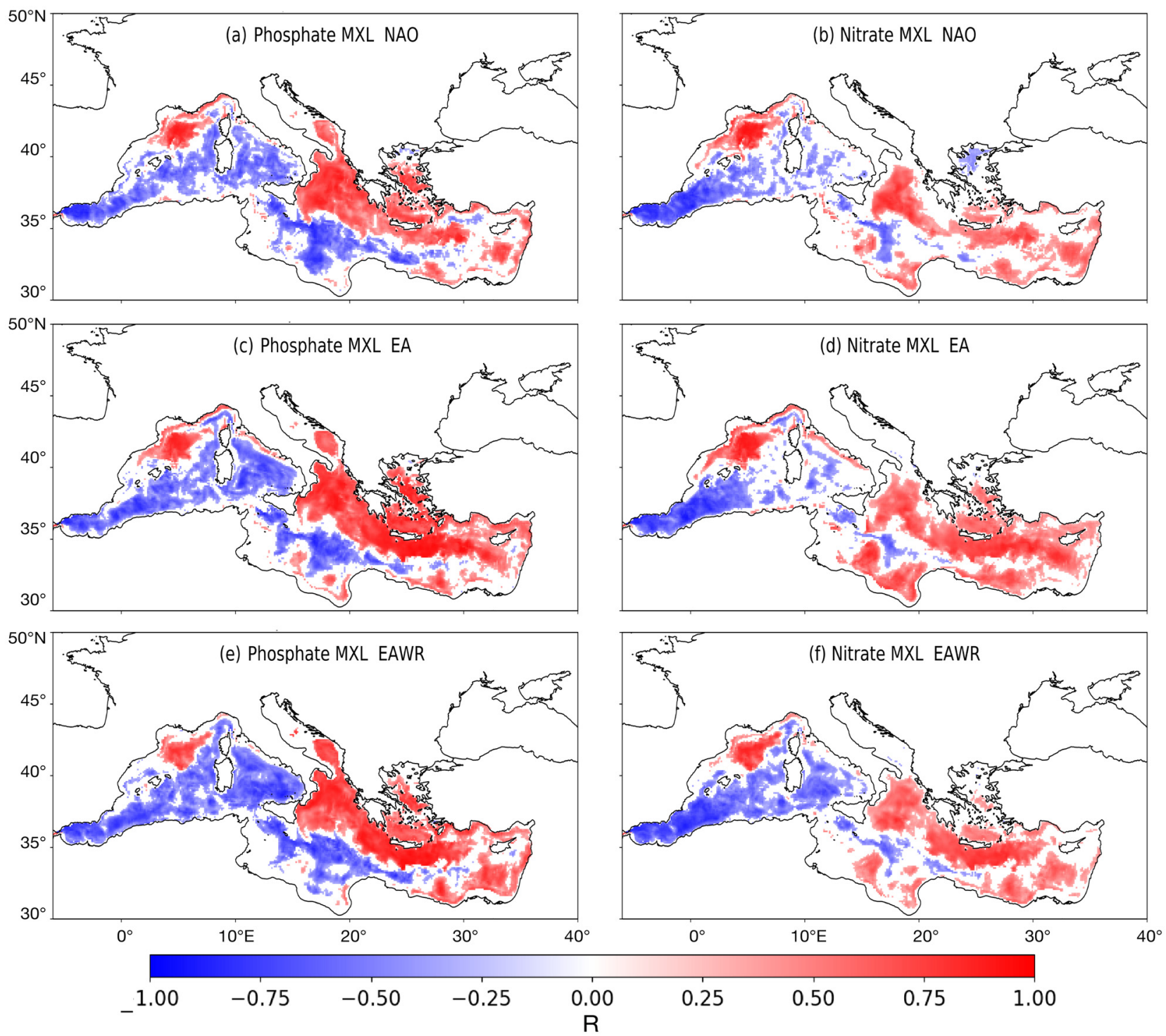

Fig. 7. Spatial correlation between anomalous $\mathrm{PO}_{4}$ (left column) and $\mathrm{NO}_{3}$ (right column) and anomalous mixed layer depth (MXL) for a unit of positive index value. $(\mathrm{a}, \mathrm{b}) \mathrm{NAO},(\mathrm{c}, \mathrm{d})$ EA and $(\mathrm{e}, \mathrm{f})$ EAWR (mode abbreviations as in Fig. 4). Only values significant at $95 \%$ are retained

mined by the ocean's vertical processes, governing the nutrient availability in the upper layer triggered by the atmospheric dynamics. This is well illustrated in Fig. 7, which shows the spatial correlation between anomaly concentrations of $\mathrm{PO}_{4}$ and $\mathrm{NO}_{3}$ and mixed layer depth anomalies for a unit of positive index value of the NAO, EA and EAWR indices. For $\mathrm{PO}_{4}$, the maximum correlation with the mixed layer depth (with local peak correlations $>0.8$ ) is observed in the convective areas of the Gulf of Lions, Northern Ionian, Southern Adriatic Sea, Aegean Sea and Rhodes Gyre. It is worth noting, however, that lower correlations are found in wider areas of the sub-basins, suggesting a milder LACP influence on nutrient availability in the first $100 \mathrm{~m}$ outside the convection areas. On the other hand, a striking difference between $\mathrm{NO}_{3}$ and $\mathrm{PO}_{4}$ is the absence of any significant correlation for the former in the Southern Adriatic and a weaker correlation in the Northern Aegean.

\subsection{Long-term influence of LACPs on nutrient concentration}

To better investigate the link between the longterm variability of LACPs and nutrient concentrations through the mixed layer depth, we computed the correlation coefficient $r$ between the time series 
of annual mean ONDJFM values of total heat flux, wind stress curl and magnitude, mixed layer depth, $\mathrm{PO}_{4}, \mathrm{NO}_{3}$ and annual mean ONDJFM LACP indexes.

Fig. 8 shows the time series of the mean ONDJFM index for each of the LACPs over the period 19611999. The values, as in Josey et al. (2011), are means centered around January of year $n$, computed from the monthly values spanning from October (of the year $n-1$ before) to March (of the current year $n$ ). For example, $\mathrm{NAO}_{1962}$, i.e. the mean value of the NAO index for 1962, is defined as:

$$
\begin{gathered}
\left(\mathrm{NAO}_{\text {oct1961 }}+\mathrm{NAO}_{\text {nov1961 }}+\mathrm{NAO}_{\text {dec1961 }}+\right. \\
\left.\mathrm{NAO}_{\text {jan1962 }}+\mathrm{NAO}_{\text {feb1962 }}+\mathrm{NAO}_{\text {mar1962 }}\right) / 6
\end{gathered}
$$

This procedure was repeated for each year and for each LACP index. As already observed by Josey et al. (2011), both the EA and NAO indexes show an upward trend from the 1960s to the 1990s, while slightly negative trends can be observed for EAWR and SCAN, for which a negative sign is more frequent in the 1980s and 1990s. The statistical significance of the trends was tested using a Mann-Kendall test, and the tendencies for the EA, NAO and SCAN were significant. On the other hand, an analysis (not shown here) encompassing the entire period 1950-2017 showed no significant tendencies in the mean ONDJFM indexes.

In the Gulf of Lions, the EA is positively correlated with the total heat flux and negatively correlated with the wind stress magnitude and curl. Thus, a positive EA state induces a decrease in intensity and curl of wind stress and heat loss, resulting in a decrease in mixed layer depth and nutrient concentrations (both negatively correlated with the EA index, with $\mathrm{r}=$ -0.41 for $\mathrm{PO}_{4}$ and -0.51 for $\mathrm{NO}_{3}$ ). The lower correlation value for $\mathrm{PO}_{4}$ is likely associated with the alleged phosphorus limitation of the Mediterranean Sea, implying that, when available, $\mathrm{PO}_{4}$ is consumed earlier than $\mathrm{NO}_{3}$ by phytoplankton and bacteria (Lazzari et al. 2016). This in turn implies that $\mathrm{PO}_{4}$ is not conserved in its inorganic form, and the possible climatic signals in its concentration are partially blurred by biological activity. This finding is supported by the interannual correlation coefficient $r$ computed in the Gulf of Lions for each single month separately, showing that during the climatological winter season (DJF), the peak correlation between the nutrient concentrations and the EA index is reached when the biological activity is at its minimum in December ( $\mathrm{r}=-0.45$ and -0.5 , respectively) and January ( $\mathrm{r}=-0.44$ and -0.45 respectively). Also
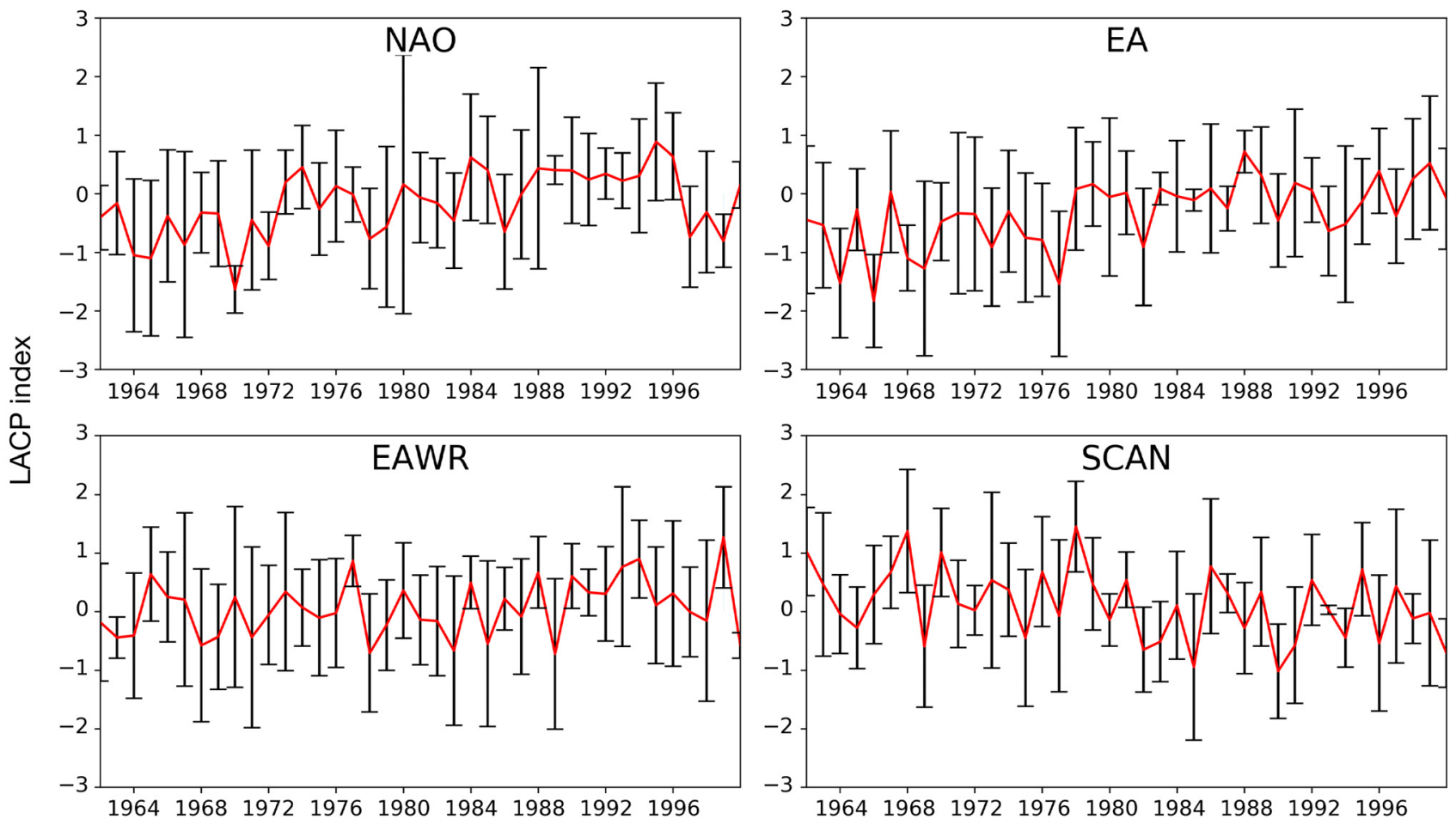

Fig. 8. Time series of the mean winter (ONDJFM) large-scale atmospheric circulation pattern (LACP) indices and related monthly standard deviation from 1961-1999. Mode abbreviations as in Fig. 4 
in the Southern Adriatic Sea, the EA is significantly correlated with the total heat flux $(\mathrm{r}=0.47)$, as also found by Josey et al. (2011). The positive EA state is thus associated with a decrease in the heat losses which, in turn, results in a decrease in the mixed layer depth and $\mathrm{PO}_{4}$ concentration (Fig. 9a).

Similar results are obtained between the NAO and $\mathrm{PO}_{4}$ in the Aegean Sea and Rhodes Gyre. The NAO is significantly correlated with the mixed layer depth in the Aegean Sea $(r=0.35)$, with this link being associated with a positive correlation of the wind stress magnitude with the NAO $(r=0.42)$. The NAO is the most significantly correlated LACP in both areas with $\mathrm{PO}_{4}(\mathrm{r}=0.58$ in the Aegean Sea and 0.47 in the Rhodes Gyre). The similar correlation values found between the Aegean Sea and the Rhodes area and the absence of any long-term significant correlation in the Rhodes Gyre between physical variables and the NAO (not shown) suggest that the long-term variability observed in the nutrient dynamics in the Rhodes area (Fig. 10) is likely associated with exchanges of properties with the nearby Aegean Sea through the Cretan Straits (Kontoyiannis et al. 1999, 2005, Krasakopoulou et al. 1999, Souvermezoglou et al. 1999). (a) Mixed Layer/Phosphate SOUTHERN ADRIATIC

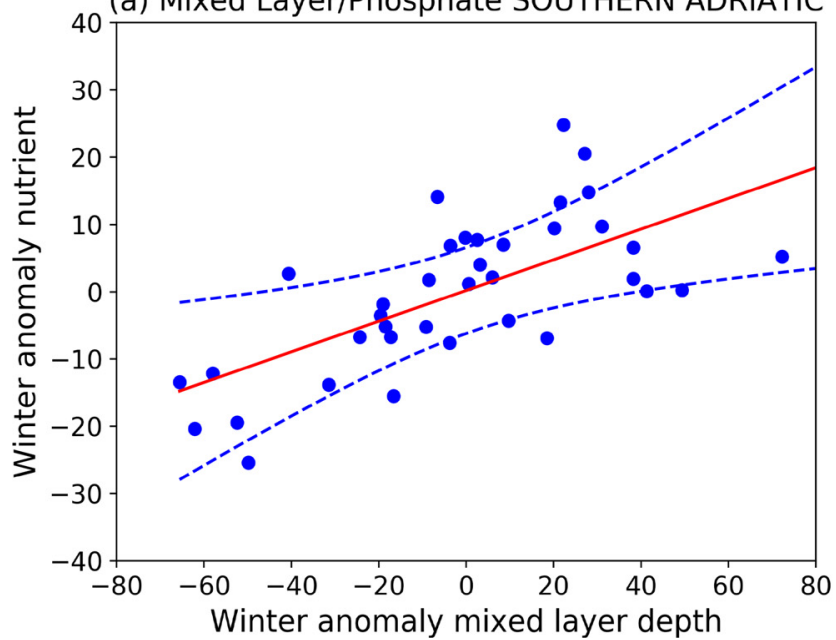

(b) River load/Nitrate SOUTHERN ADRIATIC

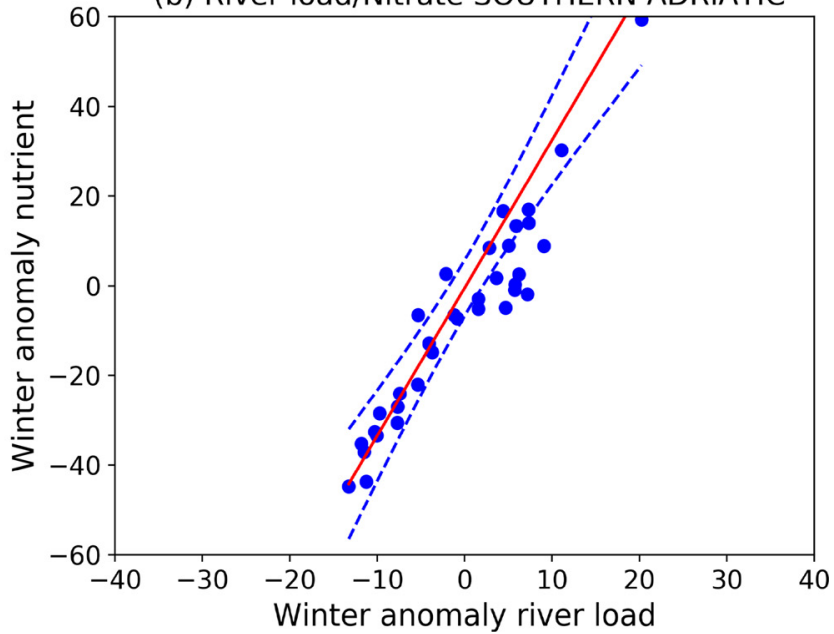

Fig. 9. (a) Winter $\mathrm{PO}_{4}$ and mixed layer depth (MXL) anomalies and (b) winter $\mathrm{NO}_{3}$ anomalies and winter river supply $\mathrm{NO}_{3}$ anomalies in the Southern Adriatic (SA) in the period 1961-1999 with linear regression (red line) and 95\% confidence level (dashed lines). All values are percentages with respect to the winter average

(a) Phosphate AEGEAN/RHODES

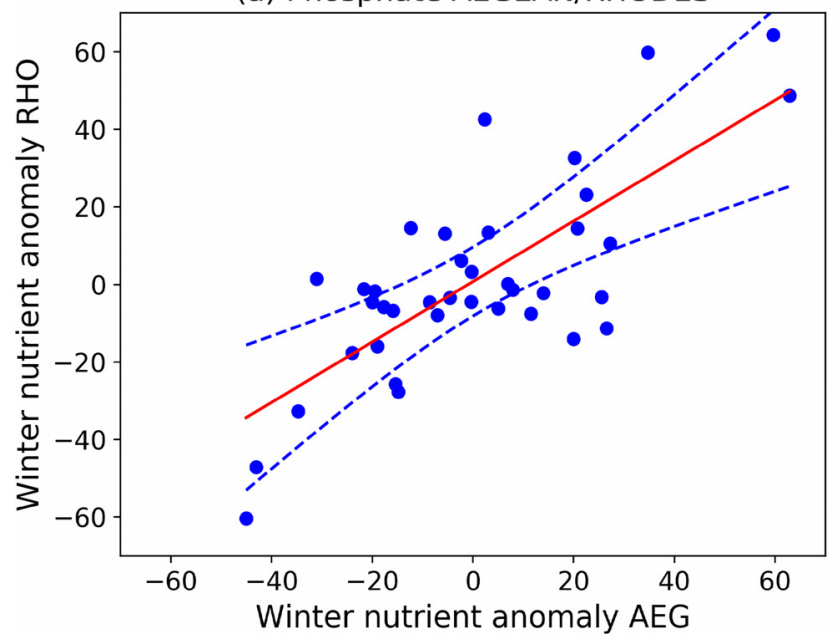

(b) Nitrate AEGEAN/RHODES

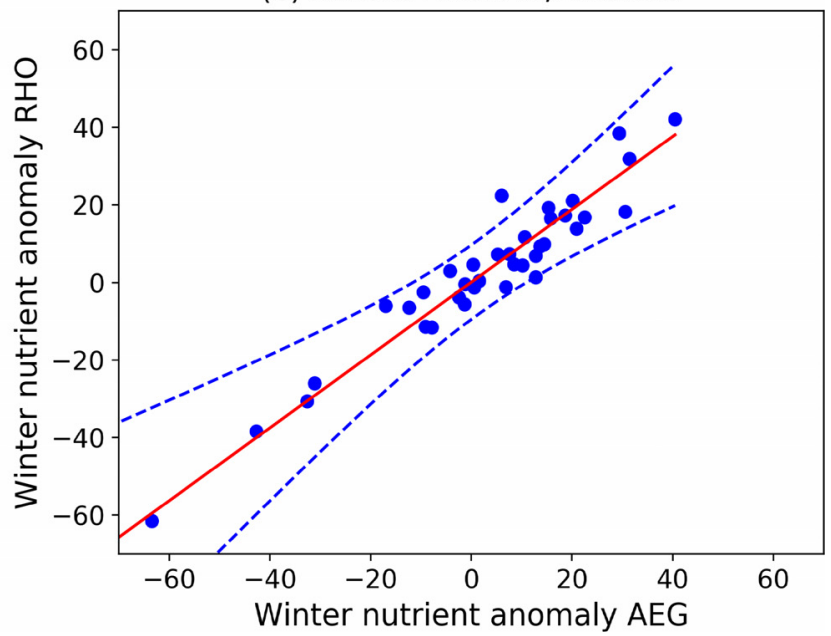

Fig. 10. (a) Winter $\mathrm{PO}_{4}$ and (b) winter $\mathrm{NO}_{3}$ anomalies in the Aegean Sea (AEG) and Rhodes Gyre (RHO) in the period 1961-1999 with linear regression (red line) and $95 \%$ confidence level (dashed line). All values are percentage with respect to the winter average 
This conclusion is further supported by the fact that the correlation coefficient between the interannual ONDJFM timeseries of $\mathrm{PO}_{4}$ in the Rhodes Gyre and Aegean Sea is high (0.75).

The explanation of the opposite signals observed in the Southern Adriatic and part of the Aegean Sea for $\mathrm{NO}_{3}$ and $\mathrm{PO}_{4}$ (Figs. $9 \& 10$ ) could be associated with the terrestrial loads of $\mathrm{NO}_{3}$ and $\mathrm{PO}_{4}$ from Adriatic rivers (mainly the Po River) and to the Dardanelles inflow and Aegean rivers (Kucuksezgin et al. 1995, Tugrul et al. 2002, Solidoro et al. 2009, Souvermezoglou et al. 2014, Cossarini et al. 2015, 2017). In fact, in the Southern Adriatic $\mathrm{NO}_{3}$ is more correlated with the river load $(\mathrm{r}=0.80)$ than with the mixed layer depth $(\mathrm{r}=-0.39)$. Thus, the dynamics of $\mathrm{NO}_{3}$ in the Southern Adriatic appear to be more influenced by river supply than LACPs, while the opposite is true for $\mathrm{PO}_{4}$ (Fig. 9). The same results are found in the Aegean Sea and Rhodes areas, where the correlation coefficients between $\mathrm{NO}_{3}$ and river loads are, respectively, 0.64 and 0.66 (Fig. 10b).

\section{CONCLUSION}

We used a long-term physical-biogeochemical hindcast covering the period 1961-1999 to quantify the effects of LACPs on the distribution of $\mathrm{NO}_{3}$ and $\mathrm{PO}_{4}$ in the Mediterranean Sea. This work is the first attempt to correlate large atmospheric circulation patterns and nutrient concentrations in the euphotic layer, with a specific focus on the convective areas of the basin, i.e. the Gulf of Lions, Southern Adriatic Sea, Southern Aegean Sea and Rhodes Gyre.

First, we showed the existence of a dipole structure in the basin associated with each teleconnection pattern. Specifically, the Gulf of Lions shows a decrease in the concentration of $\mathrm{NO}_{3}$ and $\mathrm{PO}_{4}$ corresponding with positive anomalies of EA and EAWR. A change of sign is found when we consider the NAO signal in the Southern Aegean Sea and Rhodes Gyre. For the Southern Adriatic, a positive (negative) variation is found for $\mathrm{NO}_{3}\left(\mathrm{PO}_{4}\right)$. These signals are linked to variation in the mixed layer depth associated with variation in heat losses and wind stress over the selected areas. The only exception is the $\mathrm{NO}_{3}$ variability in the Southern Adriatic, which is correlated not with the mixed layer depth, but with the river supply.

A targeted statistical analysis quantified the relative importance of these LACPs in shaping the long-term dynamics of nutrients in the selected areas. The EA pattern plays a major role in driving both $\mathrm{NO}_{3}$ and $\mathrm{PO}_{4}$ availability in the Gulf of Lions, with a particularly effective action in December and January. As found in previous studies (e.g. Josey et al. 2011, Papadopoulos et al. 2012), the physical mechanism behind this influence relies on the capability of this synoptic pattern to shape the heat fluxes and wind stress fields over the region and, as a consequence, vertical mixing, which in turn affects the concentration of nutrients triggering the phytoplankton nutrient uptake.

For both the Aegean Sea and Rhodes Gyre, the most prominent correlation is found between the NAO and $\mathrm{PO}_{4}$. The correlation analysis indicated a high consistency in the nutrient dynamics between the 2 areas. The dynamics of $\mathrm{NO}_{3}$ are more correlated with the river supply in the 2 areas than with the vertical mixing, suggesting the importance of advective signals at the Cretan Straits to transfer properties from the Aegean Sea to nearby basins. On the other hand, $\mathrm{PO}_{4}$ is more correlated with the vertical mixing in the 2 areas than with the river supply. Finally, for the Southern Adriatic there is no significant long-term correlation between the large-scale atmospheric patterns and $\mathrm{PO}_{4}$ dynamics, despite the fact that these dynamics are more influenced by vertical mixing than by river supply. The variability in the lateral advection of nutrients due to the site-specific response to the BiOS dynamics may account for this anomaly. Again, the opposite behavior is found for $\mathrm{NO}_{3}$, likely associated with river load.

In summary, our study shows that changes in the LACPs over the Mediterranean region significantly affect the nutrient dynamics in the main convective areas of the basin, although this influence is limited to the Gulf of Lions for the EA affecting $\mathrm{PO}_{4}$ and $\mathrm{NO}_{3}$ and to the Aegean Sea and Rhodes Gyre for the NAO affecting $\mathrm{PO}_{4}$ concentrations. The long-term variability in $\mathrm{NO}_{3}$ in the sub-basins of the Eastern Mediterranean seems to be more correlated with river supply than with large atmospheric circulation patterns. One of the important potential applications of this study is in the development of seasonal forecasts of nutrient loads for different areas in the Mediterranean Basin.

Acknowledgements. M.R. was supported by OGS and Cineca under HPC-TRES award number 2015-07 and by the project FAIRSEA (Fisheries in the Adriatic Region - a Shared Ecosystem Approach) funded by the 2014-2020 Interreg V-A Italy-Croatia CBC Programme (Standard project ID 100 46951). M.R. acknowledges the support of CINECA with the computational resources of IscraC ADDIO (HP10CF79DR), LEPRE (HP10C6QTCP) and TRICYCLO (HP10CYF2T3). M.R. is grateful to G. Bolzon (OGS) for his help with Python programming. We thank Michel Déqué (Météo-France) for providing the ARPERA forcing dataset. The NEMOMED8 physical simulation was performed using the Météo-France super-computer facilities. 


\section{LITERATURE CITED}

Amitai Y, Ashkenazy Y, Gildor H (2017) Multiple equilibria and overturning variability of the Aegean-Adriatic Seas. Global Planet Change 151:49-59

Amitai Y, Ashkenazy Y, Gildor H (2019) The effect of windstress over the Eastern Mediterranean on deep-water formation in the Adriatic Sea. Deep Sea Res II 164:5-13

Ashkenazy Y, Stone P, Malanotte-Rizzoli P (2012) Box modeling of the Eastern Mediterranean sea. Physica A 391: 1519-1531

Auger PA, Ulses C, Estournel C, Stemman L, Somot S, Diaz $\mathrm{F}$ (2014) Interannual control of plankton communities by deep winter mixing and prey/predator interactions in the NW Mediterranean: results from a 30-year 3D modeling study. Prog Oceanogr 124:12-27

Azov I (1991) The Mediterranean Sea, a marine desert? Mar Pollut Bull 23:225-232

Barnston G, Livezey RE (1987) Classification, seasonality and low-frequency atmospheric circulation patterns. Mon Weather Rev 115:1083-1112

Basterretxea G, Font-Muñoz JS, Salgado-Hernanz PM, Arrieta J, Hernández-Carrasco I (2018) Patterns of chlorophyll interannual variability in Mediterranean biogeographical regions. Remote Sens Environ 215:7-17

Beaugrand G, Reid P (2012) Relationships between North Atlantic salmon, plankton, and hydroclimatic change in the Northeast Atlantic. ICES J Mar Sci 69:1549-1562

Behrenfeld MJ (2010) Abandoning Sverdrup's critical depth hypothesis on phytoplankton blooms. Ecology 91:977-989

Beuvier J, Sevault F, Herrmann M, Kontoyiannis H and others (2010) Modeling the Mediterranean Sea interannual variability during 1961-2000: focus on the Eastern Mediterranean Transient. J Geophys Res 115:C08017

Cossarini G, Lazzari P, Solidoro C (2015) Spatiotemporal variability of alkalinity in the Mediterranean Sea. Biogeosciences 12:1647-1658

Cossarini G, Querin S, Solidoro C, Sannino G, Lazzari P, Di Biagio V, Bolzon G (2017) Development of BFMCOUPLER (v1.0), the coupling scheme that links the MITgcm and BFM models for ocean biogeochemistry simulations. Geosci Model Dev 10:1423-1445

Crise A, Allen J, Baretta J, Crispi G, Mosetti R, Solidoro C (1999) The Mediterranean pelagic ecosystem response to physical forcing. Prog Oceanogr 44:219-243

Crispi G, Mosetti R, Solidoro C, Crise A (2001) Nutrients cycling in Mediterranean basins: the role of the biological pump in the trophic regime. Ecol Model 138: 101-114

Cusinato E, Zanchettin D, Sannino G, Rubino A (2019) Mediterranean thermohaline response to large-scale winter atmospheric forcing in a high-resolution ocean model simulation. In: Vilibić I, Horvath K, Palau J (eds) Meteorology and climatology of the Mediterranean and Black Seas. Pageoph Topical Volumes. Birkhäuser, Cham

'D'Ortenzio F, Ribera D'Alcalà M (2009) On the trophic regimes of the Mediterranean Sea: a satellite analysis. Biogeosciences 6:139-148

D'Ortenzio F, Iudicone D, de Boyer Montegut C, Testor P and others (2005) Seasonal variability of the mixed layer depth in the Mediterranean Sea as derived from in situ profiles. Geophys Res Lett 32:L12605

* Dafner EV, Sempéré R, Bryden HL (2001) Total organic carbon distribution and budget through the Strait of Gibraltar in April 1998. Mar Chem 73:233-252
Di Biagio V, Cossarini G, Salon S, Lazzari P, Querin S, Sannino G, Solidoro C (2019) Temporal scales of variability in the Mediterranean Sea ecosystem: insight from a coupled model. J Mar Syst

* Dunić N, Vilibić I, Šepić J, Somot S, Sevault F (2018) Dense water formation and BiOS-induced variability in the Adriatic Sea simulated using an ocean regional circulation model. Clim Dyn 51:1211-1236

* Dünkeloh A, Jacobeit J (2003) Circulation dynamics of Mediterranean precipitation variability. Int J Climatol 23: 1843-1866

Foujols MA, Lévy M, Aumont O, Madec G (2000) OPA 8.1 Tracer model reference manual. Institut Pierre Simon Laplace, Paris

Gačić M, Borzelli GE, Civitarese G, Cardin V, Yari S (2010) Can internal processes sustain reversals of the ocean upper circulation? The Ionian Sea example. Geophys Res Lett 37:L09608

García-Comas C, Stemmann L, Ibanez F, Gasparini S, Mazzocchi MG, Berline L, Picheral M, Gorsky G (2011) Zooplankton long-term changes in the NW Mediterranean Sea: decadal periodicity forced by large-scale atmospheric changes. J Mar Sys 87:216-226

Giorgi F (2006) Climate change hot-spots. Geophys Res Lett 33:L08707

Giorgi F, Lionello P (2008) Climate change projections for the Mediterranean region. Global Planet Change 63: 90-104

Henson SA, Painter SC, Holliday NP, Stinchcombe MC, Giering SLC (2013) Unusual subpolar North Atlantic phytoplankton bloom in 2010: volcanic fertilization or North Atlantic Oscillation? J Geophys Res Oceans 118: 4771-4780

*Herrmann MJ, Somot S (2008) Relevance of ERA40 dynamical downscaling for modeling deep convection in the Mediterranean Sea. Geophys Res Lett 35:L04607

* Herrmann M, Sevault F, Beuvier J, Somot S (2010) What induced the exceptional 2005 convection event in the Northwestern Mediterranean basin? Answers from a modeling study. J Geophys Res 115:C12051

* Herrmann M, Diaz F, Estournel C, Marsaleix P, Ulses C (2013) Impact of atmospheric and oceanic interannual variability on the Northwestern Mediterranean Sea pelagic planktonic ecosystem and associated carbon cycle. J Geophys Res Oceans 118:5792-5813

* Houpert L, Testor P, Durrieu de Madron X, Somot S, D'Ortenzio F, Estournel C, Lavigne H (2015) Seasonal cycle of the mixed layer, the seasonal thermocline and the upperocean heat storage rate in the Mediterranean Sea: derived from observations. Prog Oceanogr 132:333-352

Huertas IE, Ríos AF, García-Lafuente J, Makaoui A and others (2009) Anthropogenic and natural $\mathrm{CO}_{2}$ exchange through the Strait of Gibraltar. Biogeosciences 6:647-662

“ Irigoien X, Harris R, Head R, Harbour D (2000) North Atlantic Oscillation and spring bloom phytoplankton composition in the English Channel. J Plankton Res 22:2367-2371

Josey SA (2003) Changes in the heat and freshwater forcing of the eastern Mediterranean and their influence on deep water formation. J Geophys Res 108:3237

Josey SA, Somot S, Tsimplis M (2011) Impacts of atmospheric modes of variability on Mediterranean Sea surface heat exchange. J Geophys Res 116:C02032

Katara I, Illian J, Pierce GJ, Scott B, Wang J (2008) Atmospheric forcing on chlorophyll concentration in the Mediterranean. Hydrobiologia 612:33-48 
Kontoyiannis H, Theocharis A, Balopoulos E, Kioroglou S and others (1999) Water fluxes through the Cretan Arc Straits, Eastern Mediterranean Sea: March 1994 to June 1995. Prog Oceanogr 44:511-529

Kontoyiannis H, Balopoulos E, Gotsis-Skretas O, Pavlidou A, Assimakopoulou G, Papageorgiou E (2005) The hydrology and biochemistry of the Cretan Straits (Antikithira and Kassos Straits) revisited in the period June 1997-May 1998. J Mar Syst 53:37-57

Krasakopoulou E, Souvermezoglou E, Pavlidou A, Kontoyiannis H (1999) Oxygen and nutrient fluxes through the Straits of the Cretan Arc (March 1994-January 1995). Prog Oceanogr 44:601-624

Kucuksezgin F, Balci A, Kontas A, Altay O (1995) Distribution of nutrients and chlorophyll-a in the Aegean Sea. Oceanol Acta 18:343-352

KLascaratos A (1993) Estimation of deep and intermediate water mass formation rates in the Mediterranean Sea. Deep Sea Res II 40:1327-1332

Lascaratos A, Roether W, Nittis K, Klein B (1999) Recent changes in deep water formation and spreading in the Mediterranean Sea: a review. Prog Oceanogr 44:5-36

Kazzari P, Solidoro C, Ibello V, Salon S and others (2012) Seasonal and inter-annual variability of plankton chlorophyll and primary production in the Mediterranean Sea: a modelling approach. Biogeosciences 9:217-233

* Lazzari P, Solidoro C, Salon S, Bolzon G (2016) Spatial variability of phosphate and nitrate in the Mediterranean Sea: a modeling approach. Deep Sea Res I 108:39-52

Lionello P, Abrantes F, Congedi L, Dulac F and others (2012) Introduction: Mediterranean climate: background information. In: Lionello P (ed) The climate of the Mediterranean region: from the past to the future. Elsevier, Amsterdam, $\mathrm{p}$ xxxc-xc

KLionello P, Trigo I, Gil V, Liberato MLR and others (2016) Objective climatology of cyclones in the Mediterranean region: a consensus view among methods with different system identification and tracking criteria. Tellus A Dyn Meteorol Oceanogr 68:29391

Kudwig W, Dumont E, Meybeck M, Heussner S (2009) River discharges or water and nutrients to the Mediterranean and Black Sea: major drivers for ecosystem changes during past and future decades? Prog Oceanogr 80:199-217

* Macias DM, Garcia-Gorriz E, Stips A (2015) Productivity changes in the Mediterranean Sea for the twenty-first century in response to changes in the regional atmospheric forcing. Front Mar Sci 2:79

Macias D, Garcia-Gorriz E, Stips A (2018) Deep winter convection and phytoplankton dynamics in the NW Mediterranean Sea under present climate and future (horizon 2030) scenarios. Sci Rep 8:6626

Manca B, Burca M, Giorgetti A, Coatanoan C, Garcia MJ, Iona A (2004) Physical and biochemical averaged vertical profiles in the Mediterranean regions: an important tool to trace the climatology of water masses and to validate incoming data from operational oceanography. J Mar Syst 48:83-116

Mann KH, Lazier JRN (1991) Dynamics of marine ecosystems: biological-physical interactions in the oceans. Blackwell Scientific Publications, Boston, MA

Mantziafou A, Lascaratos A (2004) An eddy resolving numerical study of the general circulation and deepwater formation in the Adriatic Sea. Deep Sea Res I 51: 921-952
Mantziafou A, Lascaratos A (2008) Deep-water formation in the Adriatic Sea: interannual simulations for the years 1979-1999. Deep Sea Res I 55:1403-1427

* Marullo S, Napolitano E, Santoleri R, Manca B, Evans R (2003) Variability of Rhodes and Ierapetra Gyres during Levantine Intermediate Water Experiment: observations and model results. J Geophys Res 108:8119

MEDAR Group (2003) Medatlas/2002-database: Mediterranean and Black Sea database of temperature, salinity and bio-chemical parameters. Climatological atlas (4 CD-ROMs). Elsevier Oceanogr Ser 69:645-648

* Meyssignac B, Calafat F, Somot S, Rupolo V, Stocchi P, Llovel W, Cazenave A (2011) Two-dimensional reconstruction of the Mediterranean sea level over 1970-2006 from tide gauge data and regional ocean circulation model outputs. Global Planet Change 77:49-61

* Millot C (1999) Circulation in the Western Mediterranean Sea. J Mar Syst 20:423-442

*Moutin T, Raimbault P (2002) Primary production, carbon export and nutrients availability in western and eastern Mediterranean Sea in early summer 1996 (MINOS cruise). J Mar Syst 33-34:273-288

Nittis K, Lascaratos A (1998) Diagnostic and prognostic numerical studies of LIW formation. J Mar Syst 18: 179-195

*Papadopoulos VP, Josey SA, Bartzokas A, Somot S, Ruiz S, Drakopoulou P (2012) Large-scale atmospheric circulation favoring deep- and intermediate-water formation in the Mediterranean Sea. J Clim 25:6079-6091

Pascual A, Vidal-Vijande E, Ruiz S, Somot S, Papadopoulos V (2014) Spatio-temporal variability of the surface circulation in the Western Mediterranean: a comparative study using altimetry and modeling. In: Borzelli GLE, Gacic M, Lionello P, Malanotte-Rizzoli P (eds) The Mediterranean Sea: temporal variability and spatial patterns. Geophys Monogr 202. American Geophysical Union, Washington, DC, p 5-23

*Pasqueron de Fommervault O, D'Ortenzio F, Mangin A, Serra R and others (2015) Seasonal variability of nutrient concentrations in the Mediterranean Sea: contribution of Bio-Argo floats. J Geophys Res Oceans 120: 8528-8550

Pinardi N, Arneri E, Crise A, Ravaioli M, Zavatarelli M (2006) The physical, sedimentary and ecological structure and variability of shelf areas in the Mediterranean sea. In: Robinson AR, Brink KH (eds) The sea, Vol 14. Harvard University Press, Cambridge, MA, p 1245-1330

* Pinardi N, Cessi P, Borile F, Wolfe CL (2019) The Mediterranean Sea overturning circulation. J Phys Oceanogr 49: 1699-1721

* Pinot JM, López-Jurado JL, Riera M (2002) The Canales experiment (1996-1998). Interannual seasonal and mesoscale variability of the circulation in the Balearic Channels. Prog Oceanogr 55:335-370

Piontkovski SA, Fonda Umani S, Stefanova K, Kamburska L, De Olazabal A (2011) An impact of atmospheric anomalies on zooplankton communities in the Northern Adriatic and Black Seas. Int J Oceans Oceanogr 1:53-71

* Polovina JJ, Mitchum GT, Evans GT (1995) Decadal and basin-scale variation in mixed layer depth and the impact on biological production in the central and Northern Pacific, 1960-88. Deep Sea Res I 42:1701-1716

* Reale M, Lionello P (2013) Synoptic climatology of winter intense precipitation events along the Mediterranean coasts. Nat Hazards Earth Syst Sci 13:1707-1722 
Reale M, Crise A, Farneti R, Mosetti R (2016) A process study of the Adriatic-Ionian System baroclinic dynamics. J Geophys Res Oceans 121:5872-5887

Reale M, Salon S, Crise A, Farneti R, Mosetti R, Sannino G (2017) Unexpected covariant behavior of Aegean and Ionian Seas in the period $1987-2008$ by means of a nondimensional sea surface height index. J Geophys Res Oceans 122:8020-8033

Reale M, Giorgi F, Solidoro C, Di Biagio V and others (2020) The Regional Earth System Model RegCM-ES: evaluation of the Mediterranean climate and marine biogeochemistry. J Adv Model Earth Syst 12:e2019 MS001812

* Ribera d'Alcalà M, Civitarese G, Conversano F, Lavezza R (2003) Nutrient ratios and fluxes hint at overlooked processes in the Mediterranean Sea. J Geophys Res 108: 8106

Richon C, Dutay JC, Dulac F, Wang R and others (2018a) Modeling the impacts of atmospheric deposition of nitrogen and desert dust-derived phosphorus on nutrients and biological budgets of the Mediterranean Sea. Prog Oceanogr 163:21-39

Richon C, Dutay JC, Dulac F, Wang R, Balkanski Y (2018b) Modeling the biogeochemical impact of atmospheric phosphate deposition from desert dust and combustion sources to the Mediterranean Sea. Biogeosciences 15: 2499-2524

Kichon C, Dutay JC, Bopp L, Le Vu B, Orr JC, Somot S, Dulac F (2019) Biogeochemical response of the Mediterranean Sea to the transient SRES-A2 climate change scenario. Biogeosciences 16:135-165

Robarts RD, Zohary T, Waiser MJ, Yacobi YZ (1996) Bacterial abundance, biomass, and production in relation to phytoplankton biomass in the Levantine Basin of the southeastern Mediterranean Sea. Mar Ecol Prog Ser 137: 273-281

* Roether W, Klein B, Manca B, Theocharis A, Kioroglou S (2007) Transient Eastern Mediterranean deep waters in response to the massive dense-water output of the Aegean Sea in the 1990s. Prog Oceanogr 74:540-571

Sáenz J, Rodríguez-Puebla C, Fernández J, Zubillaga J (2001) Interpretation of interannual winter temperature variations over southwestern Europe. J Geophys Res 106: 20641-20651

* Schroeder K, Garcìa-Lafuente J, Josey SA, Artale V and others (2012) Circulation of the Mediterranean Sea and its variability. In: Lionello P (ed) The climate of the Mediterranean region: from the past to the future. Elsevier, Amsterdam, p 187-256

* Schroeder K, Chiggiato J, Bryden H, Ben Ismail S (2016) Abrupt climate shift in the Western Mediterranean Sea. Sci Rep 6:23009

Simoncelli S, Fratianni C, Pinardi N, Grandi A, Drudi M, Oddo P, Dobricic S (2019) Mediterranean Sea Physical Reanalysis (CMEMS MED-Physics) [Data set]. Copernicus Monitoring Environment Marine Service (CMEMS)

Siokou-Frangou I, Christaki U, Mazzocchi M, Montresor M, Ribera d'Alcalà M, Vaqué D, Zingone A (2010) Plankton in the open Mediterranean sea: a review. Biogeosciences 7:1543-1586

Skliris N, Sofianos S, Gkanasos A, Mantziafou A, Vervatis V, Axaopoulos P, Lascaratos A (2012) Decadal scale variability of sea surface temperature in the Mediterranean Sea in relation to atmospheric variability. Ocean Dyn 62:13-30
Smolarkiewicz PK (1983) A simple positive definite advection scheme with small implicit diffusion. Mon Weather Rev 111:479-486

Solidoro C, Bastianini M, Bandelj V, Codermatz R and others (2009) Current state, scales of variability, and trends of biogeochemical properties in the northern Adriatic Sea. J Geophys Res 114:C07S91

Somot S, Houpert L, Sevault F, Testor P and others (2018) Characterizing, modelling and understanding the climate variability of the deep water formation in the North-Western Mediterranean Sea. Clim Dyn 51:1179-1210

* Soto-Navarro J, Somot S, Sevault F, Beuvier J, CriadoAldeanueva F, García-Lafuente J, Béranger K (2015) Evaluation of regional ocean circulation models for the Mediterranean Sea at the Strait of Gibraltar: volume transport and thermohaline properties of the outflow. Clim Dyn 44:1277-1292

Sournia A (1973) La production primaire planctonique en Mediterraneee: essai de mise à jour. Bull Etude Commun Mediterr 5:1-128

* Souvermezoglou E, Krasakopoulou E, Pavlidou A (1999) Temporal variability in oxygen and nutrient concentrations in the southern Aegean Sea and the Straits of the Cretan Arc. Prog Oceanogr 44:573-600

* Souvermezoglou E, Krasakopoulou E, Pavlidou A (2014) Temporal and spatial variability of nutrients and oxygen in the North Aegean Sea during the last thirty years. Mediterr Mar Sci 15:805-822

Teruzzi A, Dobricic S, Solidoro C, Cossarini G (2014) A 3D variational assimilation scheme in coupled transport biogeochemical models: forecast of Mediterranean biogeochemical properties. J Geophys Res Oceans 119: 200-217

Teruzzi A, Cossarini G, Lazzari P, Salon S, Bolzon G, Crise A, Solidoro C (2016) Mediterranean Sea biogeochemical reanalysis (CMEMS MED REA-Biogeochemistry 19992015) Copernicus Monitoring Environment Marine Service

*Teruzzi A, Bolzon G, Salon S, Lazzari P, Solidoro C, Cossarini G (2018) Assimilation of coastal and open sea biogeochemical data to improve phytoplankton simulation in the Mediterranean Sea. Ocean Model 132:46-60

* Teruzzi A, Bolzon G, Cossarini G, Lazzari P, Salon S, Crise A, Solidoro C (2019a) Mediterranean Sea biogeochemistry reanalysis (CMEMS MED-Biogeochemistry) [Data set]. Copernicus Monitoring Environment Marine Service (CMEMS)

* Teruzzi A, Di Cerbo P, Cossarini G, Pascolo E, Salon S (2019b) Parallel implementation of a data assimilation scheme for operational oceanography: the case of the MedBFM model system. Comput Geosci 124:103-114

Theocharis A, Klein B, Nittis K, Roether W (2002) Evolution and status of the Eastern Mediterranean Transient (19971999). J Mar Syst 33-34:91-116

* Toreti A, Xoplaki E, Maraun D, Kuglitsch FG, Wanner H, Luterbacher J (2010) Characterisation of extreme winter precipitation in Mediterranean coastal sites and associated anomalous atmospheric circulation patterns. Nat Hazards Earth Syst Sci 10:1037-1050

Trigo RM, Xoplaki E, Zorita E, Luterbacher J and others (2006) Relations between variability in the Mediterranean region and mid-latitude variability. In: Lionello $\mathrm{P}$, Malanotte-Rizzoli P, Boscolo R (eds) The Mediterranean climate: an overview of the main characteristics and issues. Elsevier, Amsterdam, p 179-226 
Tugrul S, Besiktepe S, Salihoglu I (2002) Nutrient exchange fluxes between the Aegean and Black Seas through the Marmara Sea. Mediterr Mar Sci 3:33-42

Ulbrich U, Christoph M, Pinto JG, Corte-Real J (1999) Dependence of winter precipitation over Portugal on NAO and baroclinic wave activity. Int J Climatol 19:379-390

Ulbrich U, Lionello P, Belušić D, Jacobeit J and others (2012) Climate of the Mediterranean: synoptic patterns, temperature, precipitation, winds, and their extremes. In: Lionello P (ed) The climate of the Mediterranean region: from the past to the future. Elsevier, Amsterdam, p 301-346

Editorial responsibility: Eduardo Zorita, Geesthacht, Germany
*Vichi M, Cossarini G, Gutierrez Mlot E, Lazzari P and others (2013) The Biogeochemical Flux Model (BFM): equation description and user manual. BFM version 5 (BFM-V5). Release 1.1, BFM Report series N, 1. April 2014. CMCC, Bologna. http://bfmcommunity.eu

* Wallace J, Gutzler D (1981) Teleconnections in the geopotential height field during the Northern hemisphere winter. Mon Weather Rev 109:784-812

Xoplaki E (2002) Climate variability over the Mediterranean. PhD thesis, University of Bern

Submitted: November 26, 2019; Accepted: September 7, 2020 Proofs received from author(s): November 16, 2020 